\title{
PENGARUH INFRASTRUKTUR TERHADAP PERTUMBUHAN EKONOMI INDONESIA
}

\author{
Novi Maryaningsih \\ Oki Hermansyah \\ Myrnawati Savitri ${ }^{1}$
}

\begin{abstract}
The disparity on per capita income is evident between Java and outside Java in Indonesia. This paper confirms this evidence using $\sigma$-convergence statistic. Furthermore, this paper identify the determinant of per capita income by adopting the Solow growth model and $\beta$-convergence model. The result emphasize confirms the availability of basic infrastructure including electricity, road and sea transport are a necessary condition to gain high and sustainable growth. In addition, the result shows the existence of $\beta$-convergence, which represents the pace of regions with lower per capita income catching up other regions with higher per capita income, in Indonesia with 1,75\% speed of convergence; or equivalent with half-life of 41.14 years. Furthermore, the openness will increase the region's productivity due to higher technology spillover.
\end{abstract}

Keywords: $\sigma$-convergence, $\beta$-convergence, Solow growth model, income distribution, Gini coefficient, disparity.

JEL Classification: 047, 011, 018, R11

1 Peneliti ekonomi di BRE DKM, Bank Indonesia. Pandangan dalam paper ini merupakan pandangan pribadi penulis dan tidak mencerminkan pendapat resmi DKM atau Bank Indonesia. E-mail: nmaryaningsih@bi.go.id, oki_hermansyah@bi.go.id, dan myrna_savitri@bi.go.id. 


\section{PENDAHULUAN}

Modal fisik (physical capital) dan sumber daya manusia (human capital) berperan penting dalam pertumbuhan ekonomi. Ketersediaan modal fisik sangat terkait dengan ketersediaan dana investasi. Pada kasus perekonomian Indonesia, meski kinerja pertumbuhan belum mencapai rata-rata prakrisis Asia, namun fundamental perekonomian yang cukup kuat, disertai dengan perbaikan risiko makro dan mikro perekonomian, telah mendorong berbagai lembaga internasional untuk memberikan penilaian positif terhadap prospek perekonomian Indonesia. Hasilnya, Indonesia kembali dikategorikan pada peringkat layak investasi (investment grade) oleh beberapa lembaga internasional.

Plotting sederhana menunjukkan bahwa pertumbuhan ekonomi Indonesia mempunyai hubungan yang searah dengan pertumbuhan akumulasi stok kapital atau investasi (Grafik 1.1). Hal ini menunjukkan peran penting investasi atau akumulasi kapital fisik sebagai salah satu faktor penggerak pertumbuhan ekonomi Indonesia.

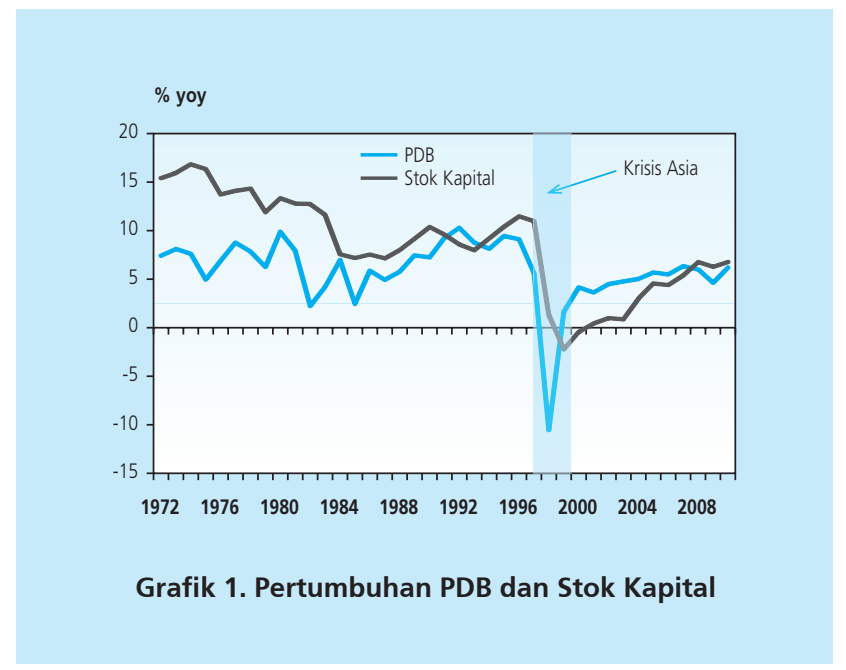

Penciptaan iklim investasi yang kondusif mendorong perkembangan positif realisasi investasi yang mencapai 8,82\% pada tahun 2011. Perkembangan ini tentu saja tidak lepas dari beberapa penilaian positif terhadap Indonesia untuk kegiatan investasi. Hasil survei UNCTAD dalam World Investment Prospects Survey 2012-2014 menempatkan Indonesia pada peringkat ke empat negara tujuan investasi yang paling diminati oleh investor setelah China, Amerika Serikat, dan India (Grafik 1.2)2. Hal ini diperkuat oleh semakin positifnya persepsi iklim investasi

2 Naik 2 peringkat dibandingkan penilaian tahun sebelumnya 
di Indonesia berupa kenaikan peringkat kredit Indonesia yang telah memasuki zona investment grade berdasarkan penilaian Japan Credit Rating Agency, Fitch, dan Moody's (Grafik 3).

(Percentage of respondents selecting economy as a top destionation)

\section{$(x)=2011$ rangking}

1 China (1)

2 United States (2)

4 Indonesia (6)

5 Brazil (4)

6 Australia (8)

8 Germany (8)

8 Russian Fe

8 Thailand (12)

11 Vietnam (11)

12 Mexico (10)

13 Japan (-)

14 Netherlands

14 South Africa (-)

17 Korea, Repub

19 France (19)

19 Italy (-)

19 Malaysia (19)

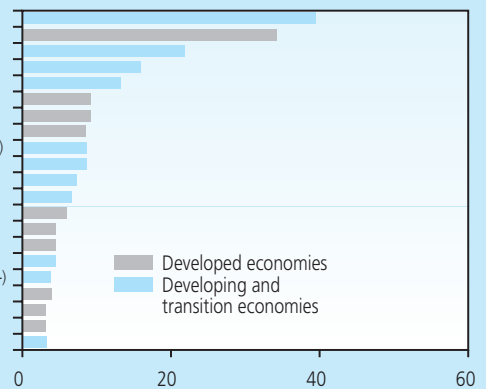

Source: UNCTAD survey.
Note: Based on 174 validated company responses

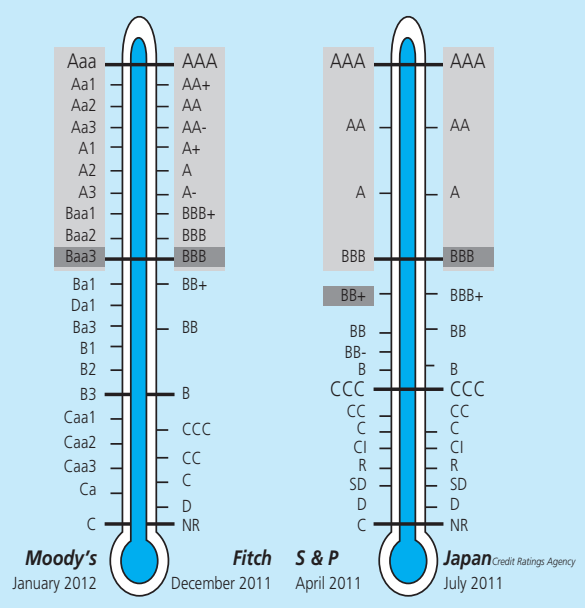

Grafik 3. Peringkat Kredit Investasi Indonesia

Grafik 2. Negara Paling Diminati Investor

Di tengah perkembangan positif tersebut, perekonomian Indonesia jangka menengah dihadapkan pada tantangan pokok yakni masih terkendalanya pembangunan faktor produksi komplementer yang menghambat pencapaian pertumbuhan ekonomi yang lebih tinggi dan berkualitas. Dalam laporan terbarunya, World Economic Forum (WEF) mengungkapkan bahwa tingkat daya saing Indonesia masih tertinggal (Tabel 1), ${ }^{3}$ terutama pada pilar infrastruktur, pilar kesiapan teknologi, dan pilar inovasi. ${ }^{3}$ Penilaian WEF ini menunjukkan bahwa kendala struktural yang dihadapi Indonesia (the most binding constraints) masih di seputar ketiga pilar tersebut dalam delapan tahun terakhir. Secara lebih spesifik, kendala pilar infrastruktur antara lain bersumber dari masih rendahnya kualitas jalan, pelabuhan, bandara, kereta hingga kualitas pasokan listrik (Tabel 2). Sementara, kendala pilar kesiapan teknologi dan inovasi di antaranya berasal dari tingkat penguasaan teknologi dan kegiatan inovasi yang masih rendah.

3 Global Competitiveness Report 2011-2012, Indonesia menempati posisi 46 dari 142 negara.

4 Indeks daya saing dibentuk dari 12 pilar yang terbagi ke dalam tiga kunci utama pendorong perekonomian, yaitu 4 pilar kebutuhan dasar (basic requirements sebagai kunci dari factor-driven economy); 6 pilar peningkatan efisiensi (efficiency enhancers sebagai kunci dari efficiency-driven economy); dan 2 pilar inovasi dan faktor kecanggihan (innovation and sophistication factors sebagai kunci dari innovation-driven economy). 


\begin{tabular}{|c|c|c|c|c|c|c|c|c|c|c|c|c|c|}
\hline \multicolumn{14}{|c|}{$\begin{array}{c}\text { Tabel } 1 \\
\text { Perkembangan Daya Saing Indonesia (1) }\end{array}$} \\
\hline $\begin{array}{l}\text { Skor } \\
\text { (skala 1-7) }\end{array}$ & 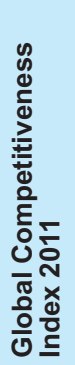 & 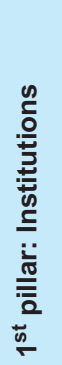 & 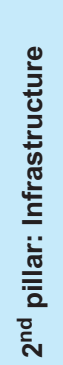 & 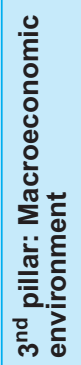 & 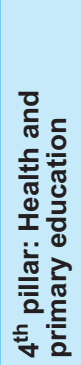 & 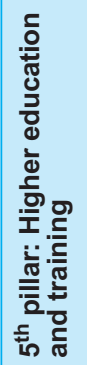 & 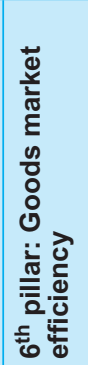 & 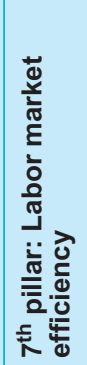 & 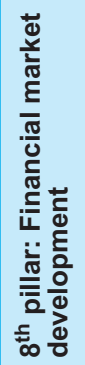 & 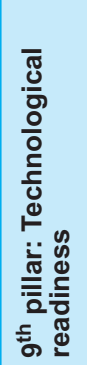 & 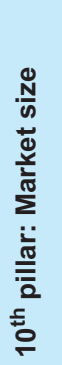 & 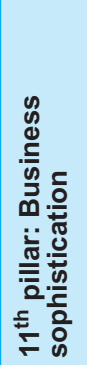 & 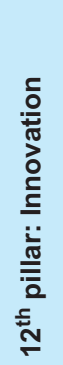 \\
\hline 2005 & 4.0 & 3.7 & 3.4 & 4.5 & 4.9 & 3.7 & 4.0 & 3.9 & 4.1 & 2.8 & 5.1 & 4.0 & 3.4 \\
\hline 2006 & 4.2 & 3.7 & 2.8 & 4.8 & 5.4 & 3.8 & 4.7 & 4.3 & 4.2 & 2.8 & 5.4 & 4.3 & 3.5 \\
\hline 2007 & 4.2 & 3.9 & 2.7 & 4.6 & 5.3 & 4.0 & 5.1 & 4.7 & 4.6 & 3.0 & 5.2 & 4.6 & 3.6 \\
\hline 2008 & 4.3 & 3.9 & 3.0 & 4.9 & 5.3 & 3.9 & 4.7 & 4.6 & 4.5 & 3.0 & 5.1 & 4.5 & 3.4 \\
\hline 2009 & 4.3 & 4.0 & 3.2 & 4.8 & 5.2 & 3.9 & 4.5 & 4.3 & 4.3 & 3.2 & 5.2 & 4.5 & 3.6 \\
\hline 2010 & 4.4 & 4.0 & 3.6 & 5.2 & 5.8 & 4.2 & 4.3 & 4.2 & 4.2 & 3.2 & 5.2 & 4.4 & 3.7 \\
\hline 2011 & 4.4 & 3.8 & 3.8 & 5.7 & 5.7 & 4.2 & 4.2 & 4.1 & 4.1 & 3.3 & 5.2 & 4.2 & 3.6 \\
\hline 2012 & 4.4 & 3.9 & 3.8 & 5.7 & 5.7 & 4.2 & 4.3 & 3.9 & 4.1 & 3.6 & 5.3 & 4.3 & 3.6 \\
\hline
\end{tabular}

\begin{tabular}{l|c|}
\multicolumn{2}{c}{ Tabel 2 } \\
\multicolumn{1}{c}{ Kualitas Infrastruktur Indonesia } \\
\multicolumn{1}{c|}{ Indikator } & Peringkat \\
\hline Kualitas keseluruhan & 92 \\
Kualitas jalan & 90 \\
Kualitas infrastruktur kereta & 51 \\
Kualitas infrastruktur pelabuhan & 104 \\
Kualitas infrastruktur transportasi udara & 89 \\
Kualitas pasokan listrik & 93 \\
Sambungan telpon/100 penduduk & 78 \\
\hline Sumber: WEF, Global Competitiveness Report, 2012-2013 \\
\hline
\end{tabular}

Terkait infrastruktur, lemahnya faktor infrastruktur juga dikonfirmasi oleh hasil survei International Institute for Management Development (IMD). Hasil surveinya pada tahun 2011 menempatkan Indonesia pada peringkat 37 dari 59 negara dengan titik lemah tingkat daya saing Indonesia terletak pada aspek infrastruktur yang meliputi infrastruktur dasar, infrastruktur teknis, infrastruktur sains, kesehatan dan lingkungan hidup, serta pendidikan (Tabel 3). 
Tabel 3

Perkembangan Daya Saing Indonesia (2)

\section{KINERJA PEREKONOMIAN}

Ekonomi Domestik

Perdagangan Internasional

PMA

Penyerapan TK

Stabilitas Harga

2. DAYA SAING PEMERINTAHAN

Keuangan Publik

Kebijakan Fiskal

Kelembagaan

Legislasi Dunia Usaha

Keadilan Sosial

2005

2008

$43 \quad 55$

55

$51 \quad 55$

$45 \quad 46$

$43 \quad 45$

55

96

$45 \quad 43$

$2011 \quad 2005-2011$

3. DAYA SAING DUNIA USAHA

Produktivitas/Efisiensi

Ketenagakerjaan

Kualitas Sistem Keuangan

Kualitas Manajerial

Nilai-nilai dan Norma

4. DAYA SAING INFRASTRUKTUR

Infrastruktur Dasar

Infrastruktur Teknis

Infrastruktur Sains

Kesehatan dan LH

Pendidikan

Sumber: IMD, 2011

Selain lemahnya faktor produksi komplementer tersebut, kualitas pembangunan manusia Indonesia juga dinilai masih rendah. Berdasarkan data dari UNDP, kesenjangan indeks pembangunan manusia Indonesia, baik dengan peer-groupnya maupun dengan negara di kawasan Asia Timur dan Pasifik, pascakrisis 1998 semakin melebar (Grafik 4). Hal ini berarti bahwa kualitas manusia Indonesia yang diukur dari pendidikan, kesehatan dan pendapatan, masih rendah secara relatif dibandingkan dengan negara lain, sehingga akan berdampak terhadap rendahnya tingkat daya saing perekonomian Indonesia secara keseluruhan. 


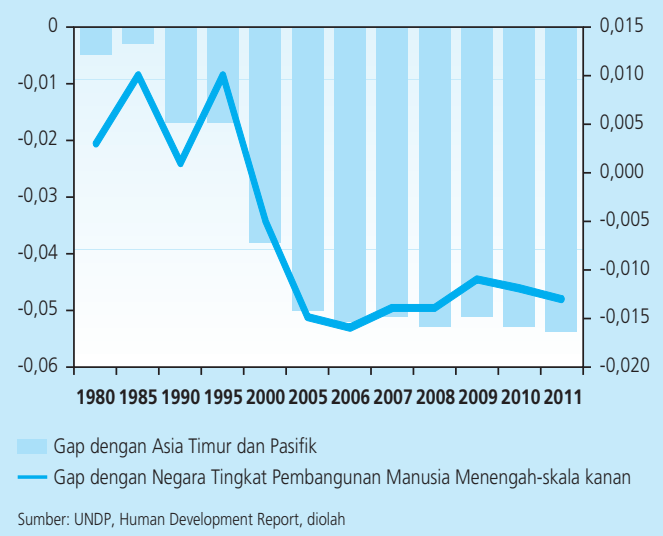

Grafik 4. Kesenjangan Indeks Pembangunan Manusia Indonesia dengan Kawasan Lain

Terkait perbaikan kondisi infrastruktur, selama ini kendala yang dihadapi adalah masalah pendanaan dan permasalahan hukum. Alokasi belanja Pemerintah untuk pembangunan infrastruktur Pemerintah dalam delapan tahun terakhir rata-rata hanya sekitar 1,6\% PDB (Grafik 5). Rasio ini relatif rendah jika dibandingkan dengan negara lain seperti China dan India, yang masing-masing mencapai 5,3\% dan 7,3\% dari PDB.

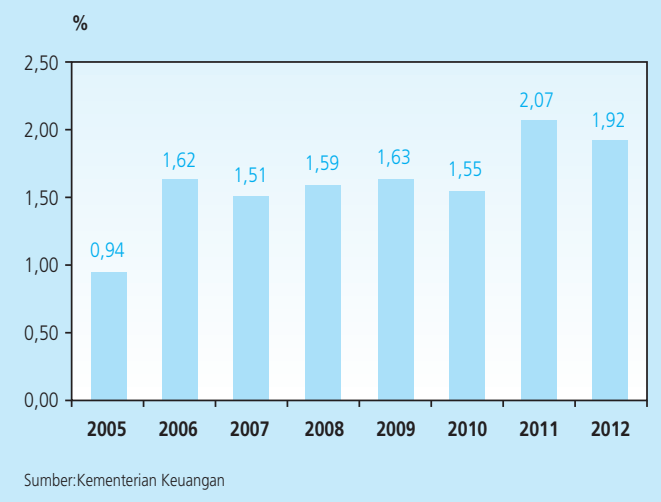

Grafik 5. Perkembangan Rasio Infrastruktur di APBN terhadap PDB 
Upaya pembenahan kondisi infrastruktur disadari peran penting dalam mengurangi kesenjangan pendapatan dan dampak jangka panjangnya bagi PDB per kapita. ${ }^{5}$ Perbaikan infrastruktur memiliki kontribusi dalam meningkatkan produktivitas dan diharapkan mampu mendukung pertumbuhan ekonomi dalam jangka panjang. Merujuk pada publikasi World Development Report (World Bank, 1994), infrastruktur berperan penting dalam meningkatkan pertumbuhan ekonomi di mana pertumbuhan ekonomi yang lebih tinggi dijumpai pada wilayah dengan tingkat ketersediaan infrastruktur yang mencukupi. Identifikasi terhadap program pembangunan infrastruktur di beberapa negara menyimpulkan bahwa pada umumnya program ditargetkan dalam jangka menengah dengan fokus pada peningkatan kebutuhan dasar dan konektivitas manusia, mulai dari air, listrik, energi, hingga transportasi (jalan raya, kereta api, pelabuhan, dan bandara). Weil (2009) juga menyatakan bahwa disparitas ketersediaan kapital fisik dan human capita/ berperan dalam menjelaskan adanya perbedaan pertumbuhan ekonomi antar negara.

Selain penelitian yang dilakukan dengan menggunakan data antar negara, terdapat beberapa penelitian dengan menggunakan data regional di suatu negara. Wu (1998) yang menyatakan bahwa derajat disparitas antar wilayah di China berbeda antara wilayah Coastal, Central, dan Western. Sementara itu, dengan menggunakan data 24 provinsi di China, Demurger (2001) menyimpulkan bahwa selain reformasi dan derajat keterbukaan, kondisi infrastruktur berperan signifikan dalam mempengaruh disparitas pertumbuhan regional. Sedangkan Calderon (2011) menyatakan bahwa pertumbuhan ekonomi berhubungan positif dan signifikan dengan stok dan kualitas infrastruktur di suatu wilayah.

Di Indonesia, banyak penelitian yang mendalami pengaruh infrastruktur terhadap perekonomian dengan hasil yang bervariasi. Sibrani (2002) menemukan bahwa infrastruktur, dalam hal ini listrik dan pendidikan, memberikan pengaruh yang positif dan signifikan pada pendapatan per kapita masyarakat Indonesia, sedangkan variabel jalan dan telepon tidak signifikan. Kebijakan pembangunan infrastruktur yang terpusat di Jawa dan Indonesia bagian barat menimbulkan disparitas pendapatan per kapita masing-masing daerah di Indonesia, terutama di Kawasan Indonesia Timur. Lebih lanjut, Yanuar (2006) dengan menggunakan data panel 26 provinsi menunjukkan bahwa modal fisik, infrastruktur jalan, telepon, kesehatan, dan pendidikan memberikan pengaruh positif pada output perekonomian. Sementara itu, Prasetyo (2008) menyimpulkan bahwa listrik, panjang jalan, stok modal, dan otoritas daerah berpengaruh positif terhadap pembangunan ekonomi Kawasan Indonesia Barat, sementara variabel air bersih tidak signifikan. Penelitian oleh Prasetyo dan Firdaus (2009) menyimpulkan bahwa pertumbuhan ekonomi Indonesia dipengaruhi oleh ketersediaan infrastruktur, di antaranya elektrifikasi, jalan beraspal, dan air bersih.

5 Lihat Calderon dan Serven (2004); dan Canning dan Pedroni (1999). 
Mengingat pentingnya peran infrastruktur dalam mendorong pertumbuhan ekonomi, maka dalam penelitian ini dilakukan kajian empiris tentang pengaruh infrastruktur fisik yang meliputi: sarana transportasi (panjang jalan dan bongkar muat pelabuhan), listrik, dan kualitas sumber daya manusia (pendidikan) terhadap 33 provinsi di Indonesia namun dengan mempertimbangkan beberapa faktor terkait kebijakan pemerintah, struktur ekonomi, dan struktur masyarakat.

Dugaan adanya disparitas di perekonomian Indonesia akan dikaji secara lebih mendalam pada penelitian ini dengan mengadopsi teori konvergensi dan menggunakan metode data panel statis dan dinamis. Secara eksplisit, tujuan dari paper ini pertama adalah memberikan gambaran terkini mengenai kondisi infrastruktur baik di tingkat nasional maupun regional; kedua, mengetahui kondisi disparitas perekonomian antar-daerah di Indonesia, yakni melalui identifikasi konvergensi; dan ketiga, mengidentifikasi pengaruh infrastruktur terhadap pertumbuhan ekonomi di tingkat nasional maupun regional.

Bagian selanjutnya dari paper ini akan mengulas teori dan studi empiris terkait. Bagian ketiga mengulas metodologi dan data yang digunakan, sementara hasil perhitungan dan estimasi serta analisisnya disajikan pada bagian keempat. Bagian kelima menyajikan kesimpulan dan menjadi bagian penutup dari paper ini.

\section{TEORI}

\subsection{Teori Pertumbuhan}

Model pertumbuhan ekonomi yang umum digunakan sebagai acuan adalah exogenous growth model atau Solow growth model. Model Solow mengasumsikan bahwa pertumbuhan ekonomi hanya dipengaruhi oleh perubahan faktor produksi modal fisik (tabungan dan investasi) dan tenaga kerja (pertumbuhan populasi), sementara teknologi yang menggambarkan tingkat efisiensi merupakan variabel eksogen dan dianggap sebagai residual. Model Solow merupakan pengembangan dari model pertumbuhan Harrod-Domar dengan menambahkan faktor tenaga kerja dan teknologi kedalam persamaan pertumbuhan. Tenaga kerja dan modal diasumsikan mengalami diminishing returns jika keduanya dianalisis secara terpisah dan constant returns to scale apabila keduanya dianalisis secara bersama-sama (Todaro dan Smith, 2006).

Model pertumbuhan Solow memakai fungsi produksi agregat, yaitu:

$$
Y=A K^{\alpha} L^{1-\alpha}
$$

dengan:

$Y$ : Produk domestik bruto (PDB)

$K$ : Stok modal fisik dan modal manusia

L : Tenaga kerja 


$$
\begin{aligned}
& A \text { : Tingkat kemajuan teknologi } \\
& \alpha \text { : Elastisitas output terhadap modal }
\end{aligned}
$$

Persamaan (1) di atas apabila dinyatakan dalam per tenaga kerja maka:

$$
\begin{gathered}
\frac{Y}{L}=A\left(\frac{K}{L}\right)^{\alpha}\left(\frac{L}{L}\right)^{1-\alpha}=A\left(\frac{K}{L}\right)^{\alpha} \\
y=A k^{\alpha}
\end{gathered}
$$

dengan:

$k$ : pendapatan per tenaga kerja

$y$ : akumulasi kapital per tenaga kerja

Dengan demikian, model pertumbuhan Solow menekankan pentingnya peranan investasi dalam proses akumulasi modal fisik (physical capital). Laju pertumbuhan ekonomi akan ditentukan oleh tingkat akumulasi kapital per tenaga kerja. Berdasarkan model ini, daerah yang memiliki akumulasi kapital lebih baik akan tumbuh lebih tinggi.

Stok kapital didefinisikan sebagai fungsi dari investasi (I) dan depresiasi (D) atau dapat dituliskan sebagai berikut:

$$
\Delta K=I-D
$$

Sehingga akumulasi kapital per tenaga kerja menjadi:

$$
\Delta k=i-d
$$

Di mana $i$ dan $d$ masing-masing merupakan jumlah investasi per tenaga kerja dan depresiasi dari kapital. Investasi diasumsikan merupakan rasio tetap $(\gamma)$ dari output, dan investasi per tenaga kerja dinotasikan sebagai:

$$
i=\gamma y
$$

Kapital diasumsikan terdepresiasi dengan laju yang konstan ( $\delta$ ) dan merupakan fungsi dari kapital sehingga dapat dituliskan:

$$
d=\delta k
$$

Sehingga akumulasi kapital per tenaga kerja dapat dituliskan sebagai fungsi dari output per tenaga kerja dan depresiasi kapital sebagai berikut: 


$$
\begin{aligned}
\Delta k & =\gamma y-\delta k \\
\Delta k & =\gamma f(k)-\delta k \\
\Delta k & =\gamma A k^{\alpha}-\delta k
\end{aligned}
$$

Steady state pada model Solow terjadi pada saat tidak terdapat lagi akumulasi kapital per tenaga kerja atau $\Delta k=0$. Dengan demikian, pada saat steady state,

$$
\begin{aligned}
& \gamma A{k_{S S}}^{\alpha}=\delta \\
& \gamma A=\delta k_{S S}^{1-\alpha} \\
& k_{S S}=(\gamma A / \delta)^{1 /(1-\alpha)}
\end{aligned}
$$

Sehingga pada saat steady state, output per tenaga kerja :

$$
\begin{aligned}
& y_{S S}=A{k_{S S}}^{\alpha} \\
& y_{S S}=A^{1 /(1-\alpha)}(\gamma / \delta)^{\alpha /(\alpha-1)}
\end{aligned}
$$

Dengan demikian, jika rasio investasi meningkat maka steady state output per tenaga kerja akan semakin tinggi. Daerah dengan kapital awal yang sama namun rasio investasi lebih tinggi akan memiliki steady state pendapatan per kapita lebih tinggi (Grafik 6) sehingga ketimpangan (disparitas) antar daerah akan semakin lebar. Sementara itu, daerah dengan kapital awal lebih rendah namun dengan rasio investasi lebih tinggi akau tumbuh lebih tinggi (Grafik 6).
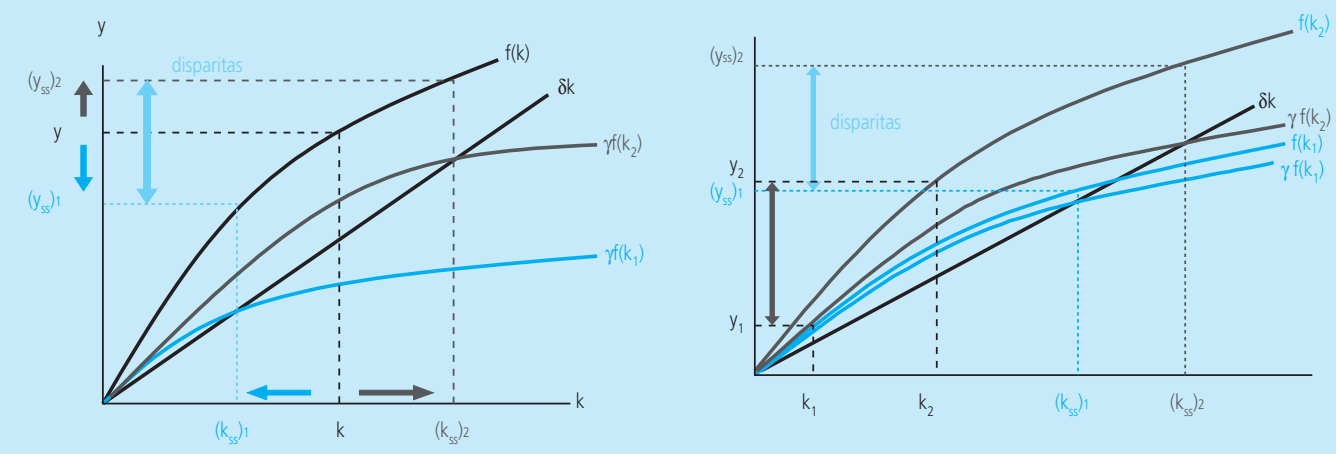

Grafik 6. Implikasi Model Solow 
Selain itu, terdapat asumsi bahwa mobilitas faktor produksi baik modal maupun tenaga kerja pada awal proses pembangunan kurang lancar sehingga modal dan tenaga kerja ahli cenderung terkonsentrasi di daerah yang lebih maju. Akibatnya terjadi ketimpangan regional yang lebar. Akan tetapi,dengan semakin baiknya prasarana dan fasilitas komunikasi di antara daerah-daerah seiring dengan proses pembangunan berkelanjutan maka mobilitas modal dan tenaga kerja akan semakin lancar. Apabila negara semakin maju, ketimpangan pembangunan regional akan berkurang. Perkiraan ini merupakan kesimpulan kedua dari model ini dan kemudian dikenal sebagai Hipotesis Neoklasik.

\subsection{Konvergensi}

Dalam literatur, indikator yang dapat digunakan untuk melihat pertumbuhan ekonomi yang inklusif adalah konvergensi yang dapat dibedakan $\sigma$-convergence dan $\beta$-convergence. Pada awalnya, $\beta$-convergence merupakan fokus pada literatur pertumbuhan ekonomi ${ }^{6}$ namun akhir-akhir ini $\sigma$-convergence mendapat perhatian lebih karena mampu menilai secara langsung distribusi pendapatan di antara daerah-daerah. ${ }^{7}$ Dengan demikian, adanya $\beta$-convergence bukan merupakan kondisi yang cukup untuk $\sigma$-convergence.

\section{$\sigma$-Convergence}

$\sigma$-convergence terjadi apabila ketimpangan pendapatan per kapita riil antar-daerah yang semakin menurun dari waktu ke waktu. Dalam penelitian ini digunakan empat ukuran $\sigma$-convergence yaitu: (i) Unweighted Coefficient of Variation, (ii) Weighted Coefficient of Variation, (iii) Theil Index, dan (iv) Gini Coefficient.

Coefficient of Variation (CV) diukur dari standar deviasi distribusi pendapatan per kapita riil provinsi-provinsi di Indonesia dibagi rata-ratanya sebagai berikut:

$$
\text { Unweighted } C V=\sqrt{\frac{\sigma\left(Y_{i}-\bar{Y}\right)^{2}}{n}} / \bar{Y}
$$

Nilai Unweighted CV yang rendah mengindikasikan adanya disparitas yang cenderung rendah. Gambar di bawah menunjukkan dua distribusi dengan rata-rata yang sama, namun distribusi dengan CV 0,1 menunjukkan disparitas yang lebih kecil dibandingkan dengan distribusi dengan CV 0,5.

6 Barro and Sala-i-Martin (1992 dan 1996), Mankiw et al (1992), dan Islam (1995)

7 Quah (1993) dan Friedman (1992) 


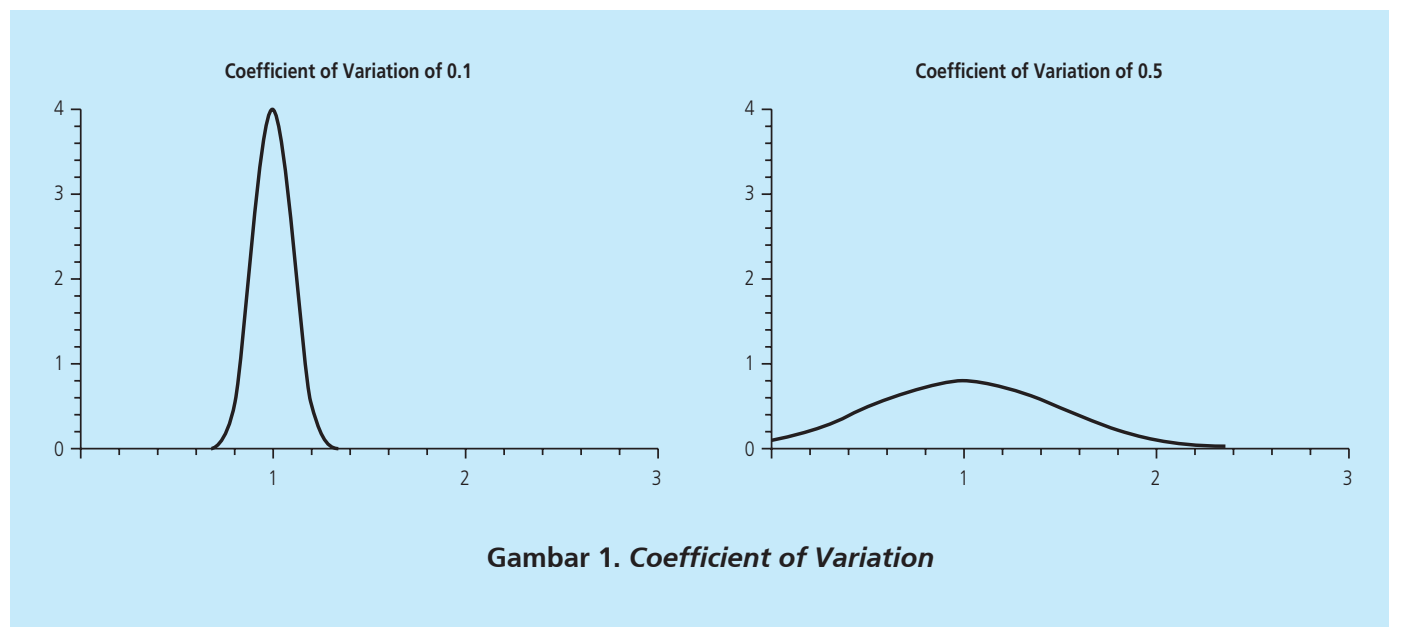

Pada sisi lain, penggunaan bobot pada perhitungan CV akan menghasilkan indikator $\sigma$-convergence yang kedua yakni weighted $C V$. Variabel yang digunakan untuk pembobotan adalah proporsi populasi suatu provinsi terhadap populasi nasional.

$$
\text { Weighted } C V=\sqrt{\sum p_{i}\left(Y_{i}-\mu\right)^{2}} / \mu
$$

Nilai Weighted CV yang rendah mengindikasikan adanya pemerataan pertumbuhan ekonomi yang lebih baik.

Indikator $\sigma$-convergence yang ketiga adalah Theil Index yang merupakan kontribusi tiap provinsi terhadap inequality antar provinsi. Provinsi terkaya akan menyumbangkan Theil index positif yang besar, sedangkan provinsi termiskin menyumbangkan Theil index negatif yang besar.

$$
\text { Theil Index }=\sum Y_{i} \log \left(\frac{Y_{i}}{\bar{Y}}\right) / n \bar{Y}
$$

Indikator $\sigma$-convergence yang keempat adalah koefisien Gini. Perhitungan disparitas dengan menggunakan koefisien Gini dibangun berdasarkan kurva Lorenz yang merupakan plotting kumulatif persentase populasi dengan kumulatif tingkat pendapatan riil tertentu. Gini Coefficient (luas daerah C) merupakan selisih antara bagian pendapatan yang merata (luas segitiga yang dibatasi garis A) dengan luas kurva Lorenz (luas daerah B). 


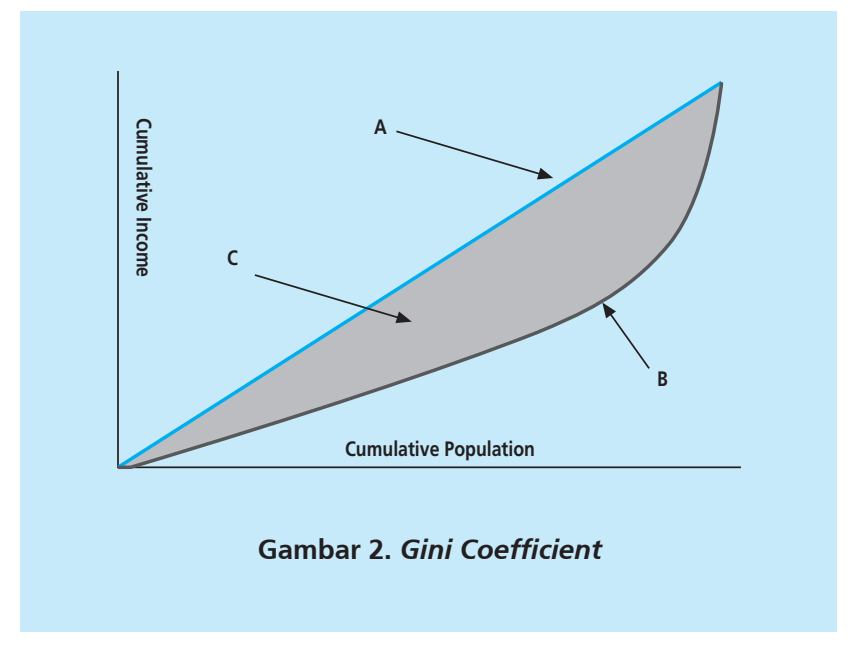

Dengan demikian, Gini Coefficient yang makin kecil menunjukkan disparitas yang semakin kecil.

$$
\text { Gini Coefficient }=\sum \sum \sqrt{Y_{i}-Y_{j}} / 2 n^{2} \bar{Y}
$$

dengan

$p_{i}:$ share dari populasi wilayah i (terhadap total nasional)

$Y_{i}$ : pendapatan per kapita provinsi $i$

$Y_{j}$ : pendapatan per kapita selain provinsi $i$

$Y$ : rata-rata pendapatan per kapita

$\mu$ : pendapatan rata-rata tertimbang populasi, yaitu

$n$ : banyaknya wilayah

\section{$\beta$-Convergence}

Estimasi $\beta$-convergence mulai dipopulerkan oleh Islam (1995) untuk mengukur seberapa cepat daerah miskin mengejar ketertinggalannya terhadap daerah yang lebih kaya. Kegunaan penggunaan estimasi ini dengan data panel adalah (i) permasalahan omitted variables dapat dikendalikan, terutama terkait adanya perbedaan tingkat teknologi inisial antar daerah; dan (ii) masalah endogeneity dan kesalahan pengukuran dapat diatasi (Islam, 2003; Bond et al., 2001). Dalam paper ini, persamaan $\beta$-convergence yang akan diestimasi mendasarkan pada model pertumbuhan Solow, yaitu pendapatan per kapita sebagai fungsi dari kapital per kapita. Modifikasi dilakukan dengan mengembangkan kapital per kapita menjadi dua kelompok besar, yaitu (i) faktor produksi (modal fisik dan modal manusia) dan (ii) infrastruktur. Variabel kontrol 
juga turut disertakan sebagai alat bantu dalam mendapatkan model yang robust. Secara garis besar, model yang akan diestimasi dalam paper ini adalah sebagai berikut:

$$
\begin{array}{r}
\ln y_{i t}-\ln y_{i t-1}=\alpha_{i}+\eta_{t}+\beta \ln y_{i t-1}+\gamma X_{i t} \\
+\phi Z_{i t}+\psi W_{i t}+\varepsilon_{i t} ; \text { untuk } \beta=e^{-\tau t}-1
\end{array}
$$

atau dapat pula dinyatakan sebagai:

$$
\begin{gathered}
\ln y_{i t}=\alpha_{i}+\eta_{t}+\rho \ln y_{i t-1}+\gamma X_{i t}+\phi Z_{i t} \\
+\psi W_{i t}+\varepsilon_{i t} ; \text { dengan } \rho=e^{-\tau t}
\end{gathered}
$$

Parameter $\tau$ menyatakan tingkat konvergensi suatu negara, dan

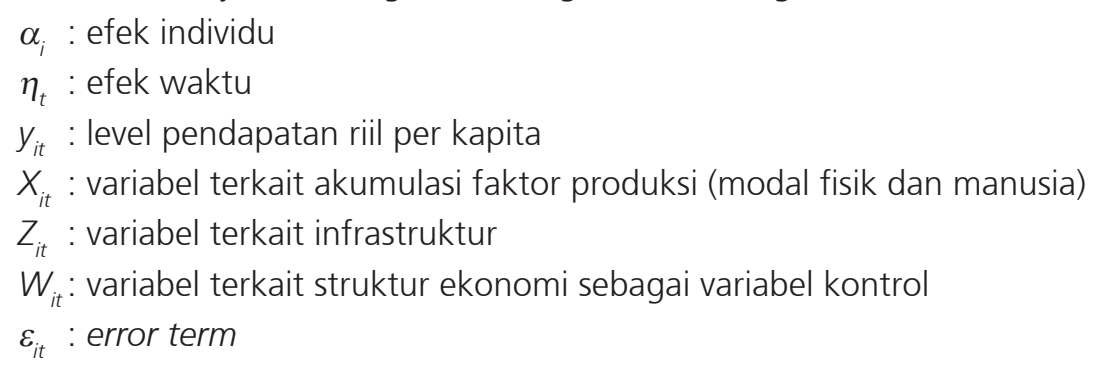

Keberadaan lag variabel dependen di ruas kanan memunculkan permasalahan endogeneity sehingga penggunaan metode data panel dinamis menjadi lebih tepat sebagaimana akan dijelaskan pada bagian metodologi.

\section{METODOLOGI}

\subsection{Data, Variabel, dan Model Empiris}

Dalam pengujian ini, kapital dibagi menjadi dua kelompok, yaitu (i) faktor produksi yang terdiri dari modal fisik dan modal manusia; dan (ii) infrastruktur. Modal fisik berupa kapital didekati dengan variabel investasi riil mengingat terbatasnya ketersediaan data stok kapital per daerah. Sementara itu, variabel modal manusia menggunakan data rata-rata masa sekolah. Terkait infrastruktur, besaran yang digunakan dalam estimasi ini mencakup indikator transportasi (panjang jalan dan bongkar muat pelabuhan) dan indikator kelistrikan (jumlah pelanggan) untuk melihat peran infrastruktur keras terhadap tingkat pendapatan per kapita.

Dengan mempertimbangkan ketersediaan data, estimasi persamaan (9) menjadi sebagai berikut:

$$
\begin{aligned}
& P D R B_{i t}=\alpha_{i t}+\beta_{1} P D R B_{i t-1}+\beta_{2} P^{2} M T B_{i t}+\beta_{3} A Y S_{i t}+\beta_{4} E L E C_{i t}+\beta_{5} R O A D_{i t} \\
& +\beta_{6} L O A D_{i t}+\beta_{7} U R B A N_{i t}+\beta_{8} O P E N_{i t}+\beta_{9} C S G R L_{i t}+\beta_{10} Y A G R_{i t}+\varepsilon_{i t}
\end{aligned}
$$


di mana

PDRB : : PDRB riil per kapita;

PMTB : pembentukan modal tetap bruto riil per kapita;

AYS : rata-rata masa sekolah;

ELEC : jumlah pelanggan listrik per kapita;

ROAD : panjang jalan per kapita;

$\angle O A D \quad$ : bongkar muat pelabuhan per kapita;

URBAN : persentase masyarakat yang tinggal di kawasan perkotaan;

OPEN : : tingkat keterbukaan perdagangan suatu wilayah;

CSGRL : pangsa konsumsi pemerintah riil terhadap total PDRB riil;

YAGR : : pangsa PDRB sektor pertanian terhadap PDRB;

Semua variabel diestimasi dalam bentuk logaritma natural. Adapun detail besaran yang digunakan dan ekspektasi tanda sebagai berikut:

\begin{tabular}{|c|c|c|c|c|c|}
\hline \multicolumn{6}{|c|}{$\begin{array}{c}\text { Tabel } 4 \\
\text { Jenis dan Sumber Data }\end{array}$} \\
\hline Variabel & Data & Satuan & $\begin{array}{c}\text { Ekspektasi } \\
\text { Tanda }\end{array}$ & Sampel & Sumber \\
\hline PDRB & $\begin{array}{l}\text { Produk Domestik Regional } \\
\text { Bruto Riil }\end{array}$ & Rp miliar & & $2000-2010$ & BPS \\
\hline POPNL & Populasi & Ribu orang & & $2000-2010$ & $\begin{array}{l}\text { BPS: Statistik } \\
\text { Indonesia }\end{array}$ \\
\hline PMTB & Investasi Riil & Rp miliar & + & $2000-2010$ & BPS \\
\hline AYS & Rata-rata Masa Sekolah & Tahun & + & $2000-2010$ & $\begin{array}{l}\text { BPS: Statistik } \\
\text { Indonesia }\end{array}$ \\
\hline ELEC & Jumlah Pelanggan & Orang & + & $2000-2010$ & PLN: Statistik PLN \\
\hline ROAD & Panjang Jalan & $\mathrm{Km}$ & + & $2000-2010$ & $\begin{array}{l}\text { BPS: Statistik } \\
\text { Transportasi }\end{array}$ \\
\hline LOAD & Bongkar Muat Pelabuhan & Ton & + & $2000-2010$ & $\begin{array}{l}\text { BPS: Statistik } \\
\text { Transportasi }\end{array}$ \\
\hline URBAN & Jumlah Penduduk Perkotaan & $\%$ Populasi & + & $2000-2010$ & BPS \\
\hline OPEN & Tingkat Keterbukaan & $\%$ & + & $2000-2010$ & BPS \\
\hline CSGRL & Konsumsi Pemerintah & Rp miliar & - & $2000-2010$ & BPS \\
\hline YAGR & PDRB Riil Sektor Pertanian & Rp miliar & $+/-$ & $2000-2010$ & BPS \\
\hline
\end{tabular}

Variabel kontrol terdiri dari (i) urbanisasi yang menggambarkan rasio jumlah penduduk yang tinggal di perkotaan relatif terhadap total populasi di suatu wilayah; (ii) tingkat keterbukaan suatu wilayah; (iii) pangsa konsumsi pemerintah terhadap total PDRB; dan (iv) pangsa PDRB sektor pertanian. Variabel urbanisasi digunakan untuk menangkap struktur masyarakat perkotaan yang cenderung bekerja di sektor manufaktur dan jasa ketimbang sektor pertanian, 
sehingga perannya dalam mendorong pendapatan per kapita (penciptaan nilai tambah) cukup besar. Karenanya, digunakan pula pangsa PDB sektor pertanian sebagai variabel kontrol untuk menangkap dugaan pertumbuhan produktivitas sektor pertanian yang lebih kecil dibanding sektor manufaktur dan/atau jasa sehingga memperlambat laju pertumbuhan pendapatan per kapita. Sementara itu, openness menggambarkan tingkat keterbukaan suatu provinsi terhadap perdagangan internasional. Terakhir, variabel konsumsi pemerintah dijadikan variabel kontrol untuk melihat konsekuensi apabila pemerintah lebih memberi perhatian terhadap belanja selain belanja modal/investasi.

Hipotesis yang diajukan dalam pengujian ini adalah sebagai berikut. Hipotesis $\beta$-convergence adalah positif, yakni terjadi proses konvergensi dalam perekonomian Indonesia. Faktor produksi kapital yang terdiri dari modal fisik yaitu investasi dan berbagai infrastruktur keras seperti listrik, jalan, dan bongkar muat pelabuhan; dan modal manusia yaitu rata-rata masa sekolah diharapkan bertanda positif yang berarti semakin besar faktor produksinya, semakin tinggi pula pertumbuhan pendapatan per kapitanya.

Urbanisasi diharapkan bertanda positif, artinya semakin banyak masyarakat perkotaan yang cenderung bekerja di sektor manufaktur dan jasa ketimbang sektor pertanian akan mendorong pendapatan per kapita. Sebaliknya, pangsa PDB sektor pertanian yang semakin besar akan memperlambat laju pertumbuhan pendapatan per kapita karena relatif rendahnya produktivitas di sektor ini dibanding dengan sektor manufaktur dan/atau jasa.

Openness atau derajat keterbukaan yang semakin besar menunjukkan sektor manufaktur yang lebih produktif dan terekspos dengan perdagangan internasional semakin banyak sehingga diharapkan berdampak positif terhadap pendapatan per kapita. Terakhir, variabel konsumsi pemerintah diharapkan bertanda negatif karena tingkat konsumsi pemerintah yang semakin kecil mengindikasikan perhatian pemerintah yang lebih besar terhadap belanja modal atau investasi.

\subsection{Teknik Estimasi}

Paper ini menggunakan teknik estimasi data panel. Beberapa keuntungan penggunaan data panel diantaranya pertama, data panel mampu mengakomodasi tingkat heterogenitas variabel-variabel yang tidak dimasukkan dalam model (unobserved individual heterogeneity); kedua, mampu mengurangi kolinearitas antar-variabel; dan ketiga, estimasi data panel dapat meminimalkan bias yang dihasilkan oleh agregasi individu karena unit data lebih banyak, Baltagi (2005).

Terdapat dua metode data panel yang umum digunakan, yaitu data panel statis dan dinamis. Yang membedakan keduanya adalah pada pendekatan data panel dinamis terdapat lag dari variabel dependen yang menjadi variabel penjelas. Data panel statis terdiri dari tiga metode, yaitu pooled least square (PLS), fixed effect model (FEM), dan random effect model (REM). 
Model PLS mengasumsikan bahwa perilaku antar-individu sama dalam berbagai kurun waktu. Persamaan regresinya dapat ditulis sebagai berikut:

$$
y_{i t}=\alpha+\beta X_{i t}+\varepsilon_{i t}, \text { untuk } i=1, \ldots, N \text { dan } t=1, \ldots, T
$$

dimana $N$ adalah jumlah unit cross section (individu) dan $T$ adalah jumlah periode waktunya. Implikasinya, akan diperoleh sebanyak $T$ persamaan cross section yang sama. Begitu juga sebaliknya, dapat diperoleh persamaan time series sebanyak $N$ persamaan untuk setiap $T$ periode observasi. Namun, untuk mendapatkan parameter $\alpha$ dan $\beta$ yang konstan dan efisien, akan dapat diperoleh dalam bentuk regresi yang lebih besar dengan melibatkan sebanyak $N$ $x T$ observasi. Metode ini sederhana namun hasilnya tidak memadai karena setiap observasi diperlakukan seperti observasi yang berdiri sendiri.

Pada Fixed Effect Model (FEM), diasumsikan bahwa terdapat perbedaan antar-individu yang tergambar dari intercept masing-masing individu. Pendekatan ini digunakan apabila terdapat korelasi antara efek individu dengan regresornya. Model dengan fixed effect dapat dinyatakan dalam bentuk persamaan berikut:

$$
y_{i t}=\alpha_{i}+\lambda_{i}+\beta X_{i t}+\varepsilon_{i t}, \text { untuk } i=1, \ldots, N \text { dan } t=1, \ldots, T
$$

Terdapat dua macam komponen error $\varepsilon_{i t}$ yaitu one-way dan two-way. One-way ditandai dengan komponen error $\varepsilon_{i t}$ yang mengandung efek individu dan random error, sementara twoway ditandai dengan komponen error $\varepsilon_{i t}$ yang mengandung tidak hanya efek individu dan random error tapi juga efek waktu. Estimator pada FEM dapat dihitung dengan beberapa teknik, yaitu(1) Pendekatan Within Group (WG) dan (2) Pendekatan Least Square Dummy Variable (LSDV).

Varian ketiga dari model panel statis adalah REM. Pendekatan ini digunakan apabila tidak ada korelasi antara efek individu dengan regresornya. Model dengan random effect dapat dinyatakan dalam bentuk persamaan berikut:

$$
y_{i t}=\alpha_{i}+\beta X_{i t}+\lambda_{i}+\varepsilon_{i t}, \text { untuk } i=1, \ldots, N \text { dan } t=1, \ldots, T
$$

Estimator pada REM dapat dihitung dengan beberapa teknik, yaitu (1) Pendekatan Between Estimator dan (2) Generalized Least Square (GLS).

Untuk menentukan pendekatan yang lebih baik antara fixed dan random effect, dilakukan uji Hausman, yaitu untuk melihat ada tidaknya korelasi antara regresor dan efek individu dengan $\mathrm{H}_{0}$ : random effect dan $\mathrm{H}_{1}$ : fixed effect.

Di samping data panel statis, terdapat data panel dinamis yang terdiri dari dua metode, yaitu GMM first difference dan GMM system. Sebagaimana diuraikan sebelumnya, penelitian ini akan mengidentifikasi indikasi proses konvergensi di perekonomian antar-daerah melalui metode $\beta$-convergence. Model yang diestimasi mengandung lag dari variabel dependen 
sebagai variabel penjelasnya. Hal ini mencirikan model dinamis namun sekaligus menimbulkan permasalahan endogenitas yang perlu diatasi. Metode GMM-system diperkenalkan oleh Blundell dan Bond (1998) sebagai pengembangan dari metode GMM-first difference dari Arellano dan Bond (1991). Estimator GMM-system pada dasarnya menggunakan variabel lag first-difference sebagai instrumen bagi persamaan di tingkat level.

Konsistensi estimator GMM bergantung pada validitas instrumen nilai lag autoregressive (kondisi momen) di persamaan regresi yang diuji. Estimasi yang dilakukan mensyaratkan ortogonalitas antara error term di first difference dan lag dari variabel dependen, artinya tidak ada hubungan antara error tersebut dengan lag variabel dependen. Ini diperlukan untuk menjamin estimator yang tidak bias dan konsisten. Untuk menguji kondisi ortogonalitas tersebut, akan dilakukan pengujian serial correlation di orde pertama dan kedua (Arellano dan Bond (1991), dan Roodman (2009a, b)) dengan tiga uji spesifikasi, yaitu $A R(1)$, $A R(2)$ dan uji Hansen.

Model data panel yang robust ditandai dengan hasil uji statistik $A R(1)$ yang menolak hipotesis adanya serial correlation di orde satu, dan hasil uji statistik $A R(2)$ yang tidak menolak hipotesis tidak adanya serial correlation di orde dua. Sementara itu, untuk menguji validitas keseluruhan terhadap variabel instrumen, digunakan uji over-identifying restriction Hansen. dengan hipotesis nol "variabel instrumen sebagai grup bersifat eksogen" ini berarti bahwa semakin besar p-value statistik Hansen, semakin baik. Sebagai tambahan, uji Hansen juga mampu memberikan informasi mengenai validitas penambahan instrumen, yakni apabila dengan penambahan instrumen nilai statistik Hansen meningkat signifikan, maka dapat diduga terjadi pelanggaran kondisi momen. Karenanya, penerapan metode GMM-system menjadi tidak valid sedangkan metode GMM-first difference menjadi valid.

\section{HASIL DAN ANALISIS}

\section{1. $\sigma$-Convergence}

Asesmen terhadap konvergensi pendapatan per kapita riil dilakukan pada level nasional maupun per koridor sesuai dengan pembagian koridor pada MP3El yaitu Koridor Ekonomi (KE) Sumatera, Jawa, Bali Nusa Tenggara, Kalimantan, Sulawesi, dan Papua Kepulauan Maluku.

Pada level nasional terlihat bahwa pertumbuhan ekonomi selama sepuluh tahun terakhir belum menunjukkan adanya indikasi terjadinya $\sigma$-convergence. Meskipun setiap provinsi mengalami peningkatan pendapatan per kapita riil namun kesenjangan yang ada masih tetap lebar (Grafik 7). Persistensi disparitas pendapatan per kapita riil di antara provinsi-provinsi di Indonesia tercermin pula dari nilai indikator disparitas yang cenderung tidak mengalami penurunan yang signikan sepanjang sepuluh tahun terakhir. Perhitungan terhadap Weighted CV, Theil index dan Gini Coefficient memperlihatkan adanya stagnasi dari disparitas pendapatan per kapita riil. Sementara itu, meskipun indikator Unweighted CV menunjukkan kecenderungan penurunan, namun penurunan tersebut kurang signifikan (Grafik 8). 


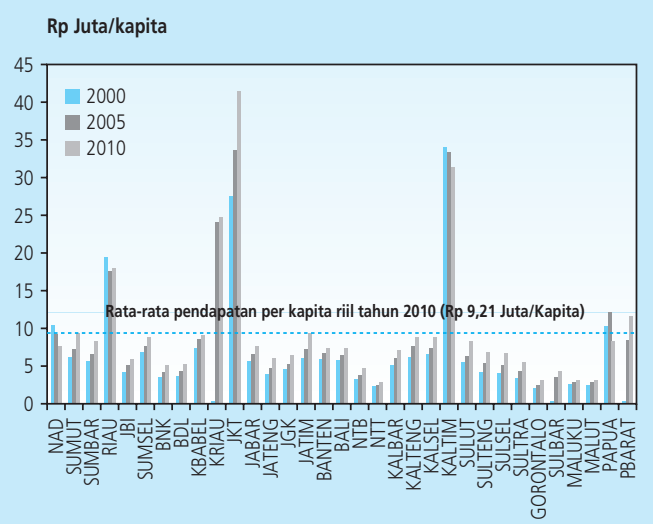

*Pendapatan per kapita riil, constan price tahun 2000 Sumber: BPS, diolah

\section{Grafik 7. Pendapatan Riil per Kapita Provinsi}

Hasil perhitungan menunjukkan bahwa Gini coefficient pendapatan per kapita riil antar provinsi di Indonesia mencapai 0,37 (tahun 2010) ${ }^{8}$ yang dinilai masih cukup tinggi menurut standar internasional. Namun, apabila mengeluarkan provinsi DKI Jakarta dan Kalimantan Timur pada perhitungan, Gini coefficient memiliki tren yang lebih rendah. Hasil perhitungan dengan mengeluarkan provinsi DKI Jakarta dan Kalimantan Timur menunjukkan bahwa Gini coefficient pada tahun 2010 adalah sebesar 0,26. Angka ini masuk dalam kategori disparitas yang rendah

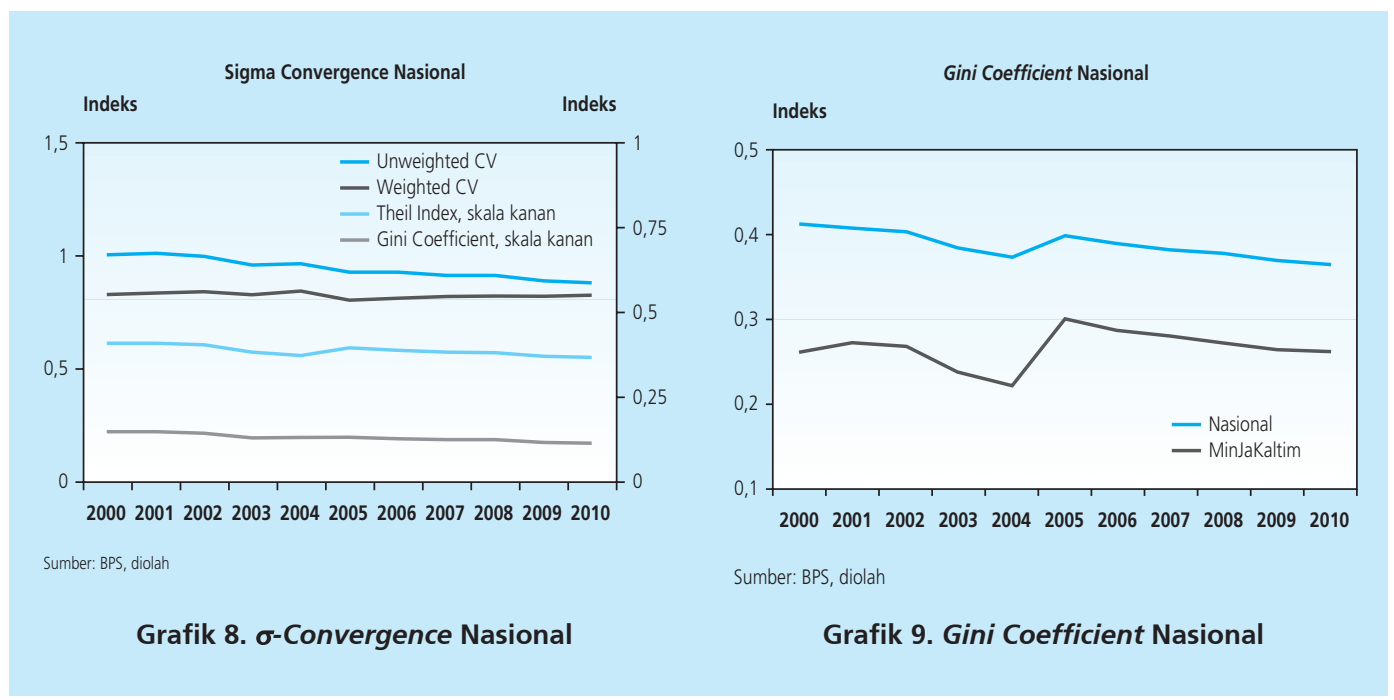

8 Gini coefficient BPS adalah 0,38 (2010) 
menurut standar internasional (Grafik 9). Hal ini mengindikasikan bahwa semakin tingginya pendapatan riil per kapita provinsi DKI Jakarta dan Kalimantan Timur ${ }^{9}$ yang tidak diikuti oleh peningkatan yang signifikan pendapatan per kapita riil provinsi-provinsi lainnya meningkatkan kesenjangan masyarakat Indonesia.

Indikator disparitas Unweighted CV dan Weighted CV menunjukkan arah yang serupa. Berdasarkan kedua grafik tersebut, terdapat indikasi adanya persistensi disparitas di KE Sumatera, Jawa, Bali dan Nusa Tenggara, serta KE Sulawesi. Sementara itu terjadi tren penurunan disparitas pendapatan per kapita riil di KE Kalimantan serta KE Papua dan Kepulauan Maluku (Grafik 10).
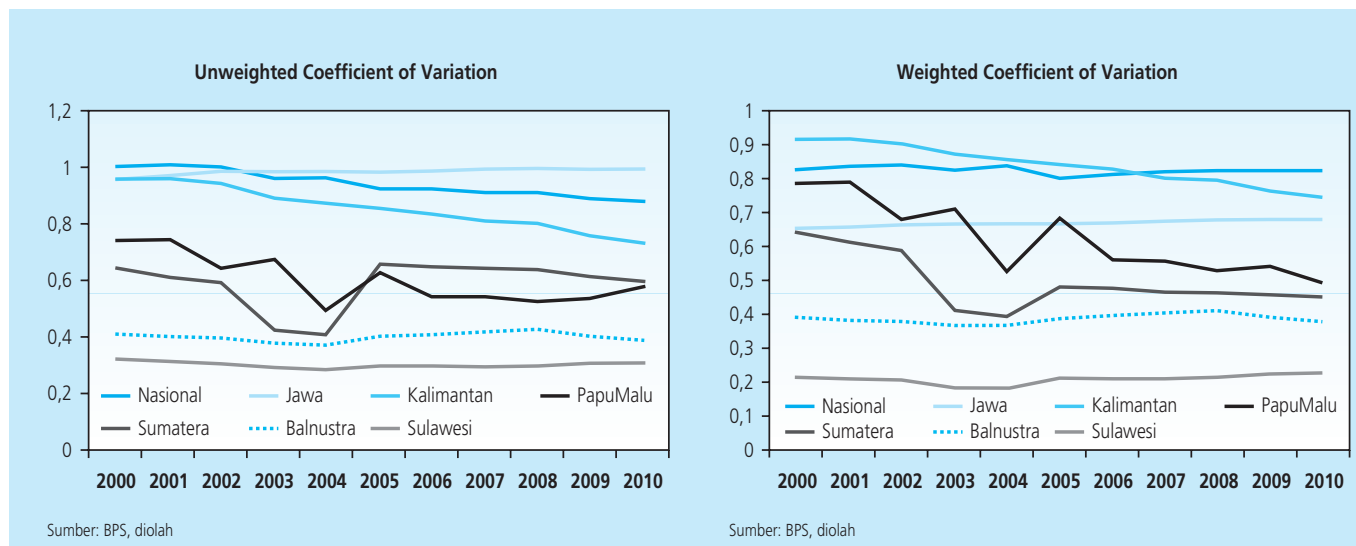

Grafik 10. Coefficient of Variation

Pengukuran disparitas dengan menggunakan Theil Index dan Gini Coefficient mengindikasikan adanya penurunan disparitas pendapatan per kapita riil pada level nasional. Pada level Koridor Ekonomi, terdapat persistensi disparitas di KE Sumatera, Jawa, Bali dan Nusa Tenggara, Sulawesi serta KE Papua dan kepualauan Maluku. Sementara itu terjadi tren penurunan disparitas pendapatan riil di KE Kalimantan. Dari sisi distribusi pendapatan, KE Sulawesi dan KE Bali dan Nusa Tenggara memiliki economic equality yang lebih bail dibandingkan KE lainnya (Grafik 11 dan Grafik 12).

9 Pendapatan per kapita riil rata-rata (2000-2010) DKI Jakarta dan Kaltim sebesar Rp 33,4 juta sementara NTT dan Gorontalo hanya sebesar Rp 2,3 juta. 


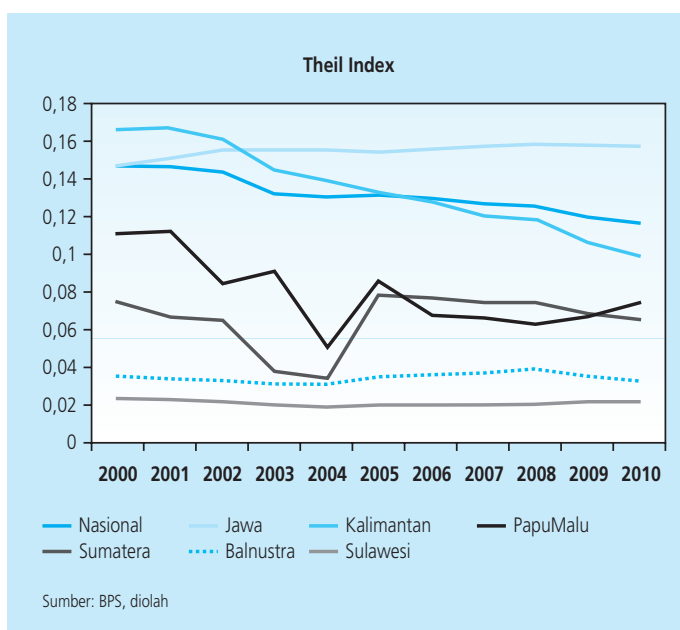

Grafik 11. Theil Index

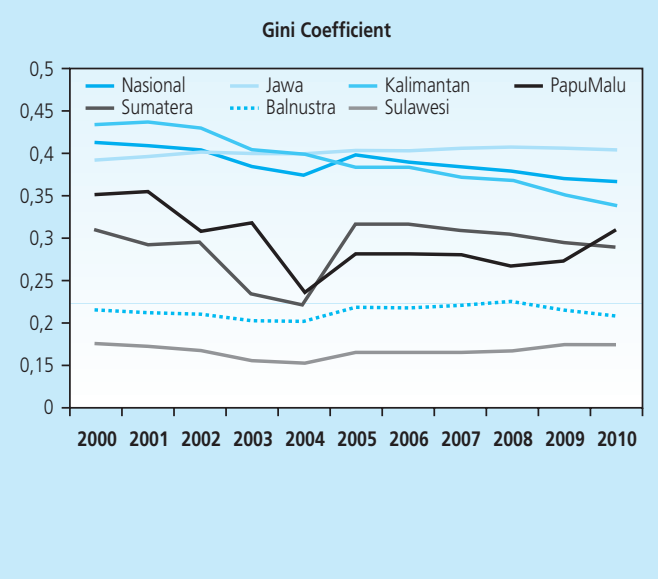

Grafik 12. Gini Coefficient

\section{Koridor Ekonomi Sumatera}

Tidak terdapat perubahan yang signifikan pada kesenjangan pendapatan riil di antara provinsi-provinsi di KE Sumatera dalam sepuluh tahun terakhir. Gini coefficient yang sempat menurun di awal kembali meningkat meskipun akhirnya kembali mengalami tren penurunan namun dengan laju yang lebih lambat dari semula. ${ }^{10} \mathrm{Hal}$ ini kemungkinan terkait dengan pemekaran provinsi Riau menjadi provinsi Riau dan provinsi Kepulauan Riau di mana kedua provinsi ini mempunyai pendapatan per kapita riil di atas provinsi-provinsi lainnya di Sumatera. Rata-rata pendapatan per kapita riil (tahun 2000-2010) KE Sumatera sebesar Rp. 8,56 juta, sementara provinsi Riau Rp. 16,95 juta dan Kep. Riau Rp. 24,56 juta. Apabila mengeluarkan provinsi Riau dan Kep. Riau, rata-rata pendapatan riil provinsi di KE Sumatera hanya sebesar Rp. 6,4 juta (Grafik 13). Munculnya provinsi baru dengan pendapatan per kapita yang lebih tinggi dibanding rata-rata di KE Sumatera menyebabkan kesenjangan yang semakin lebar. 


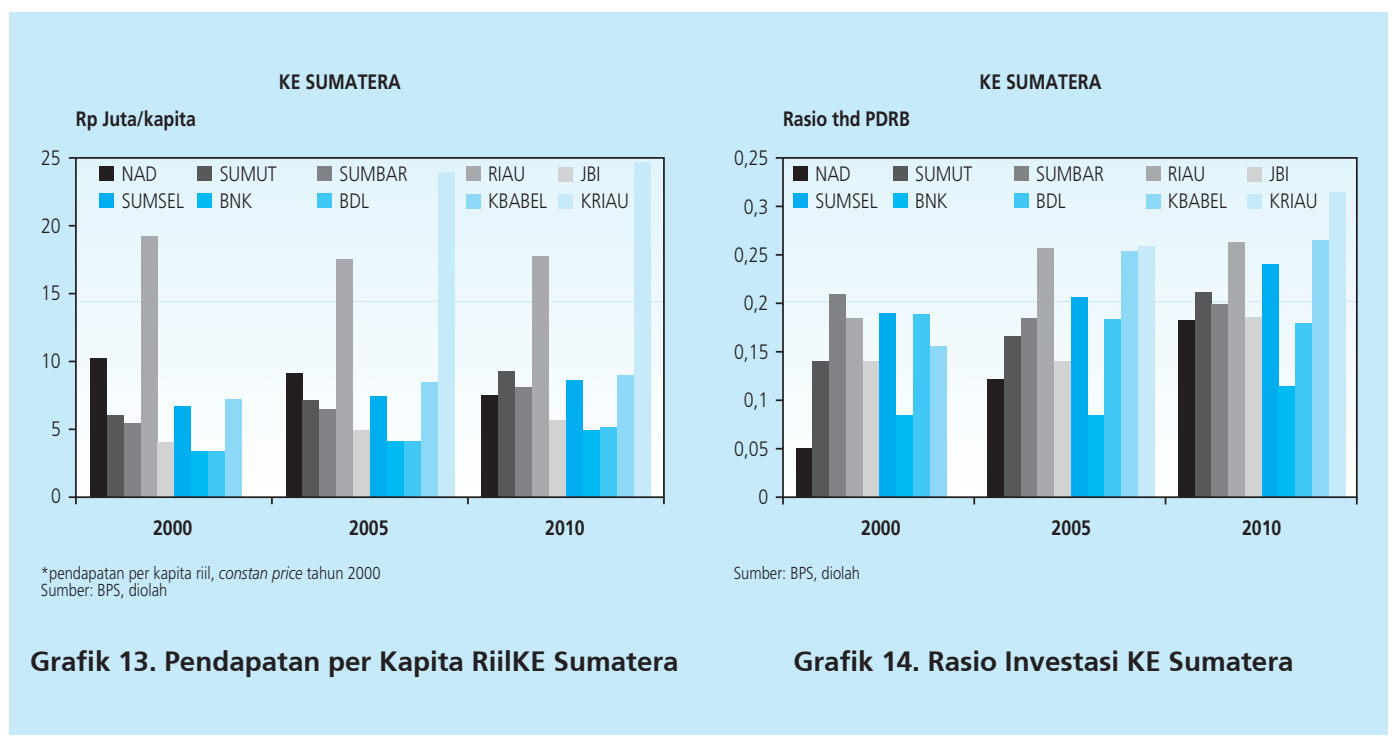

Selain mempunyai kinerja perekonomian yang lebih baik, provinsi Riau dan Kep.Riau memiliki rasio investasi yang lebih tinggi dibandingkan provinsi-provinsi lainnya di KE Sumatera (Grafik 14). Hal ini mengindikasikan bahwa investasi mempunyai pengaruh positif dalam menggerakkan perekonomian di KE Sumatera.

\section{Koridor Ekonomi Jawa}

Dalam sepuluh tahun terakhir, disparitas pendapatan riil provinsi di KE Jawa mengalami persistensi. ${ }^{11}$ Pendapatan per kapita riil DKI Jakarta yang tinggi belum bisa diimbangi oleh provinsi-provinsi lain di KE Jawa. Rata-rata pendapatan per kapita riil (2000-2010) di KE Jawa sebesar Rp. 10,57 juta, sementara pendapatan per kapita riil DKI Jakarta mencapai Rp. 33,86 juta. Apabila mengeluarkan DKI Jakarta dari perhitungan, pendapatan riil rata-rata provinsi di KE Jawa hanya menjadi Rp. 5,9 juta (Grafik 15). 


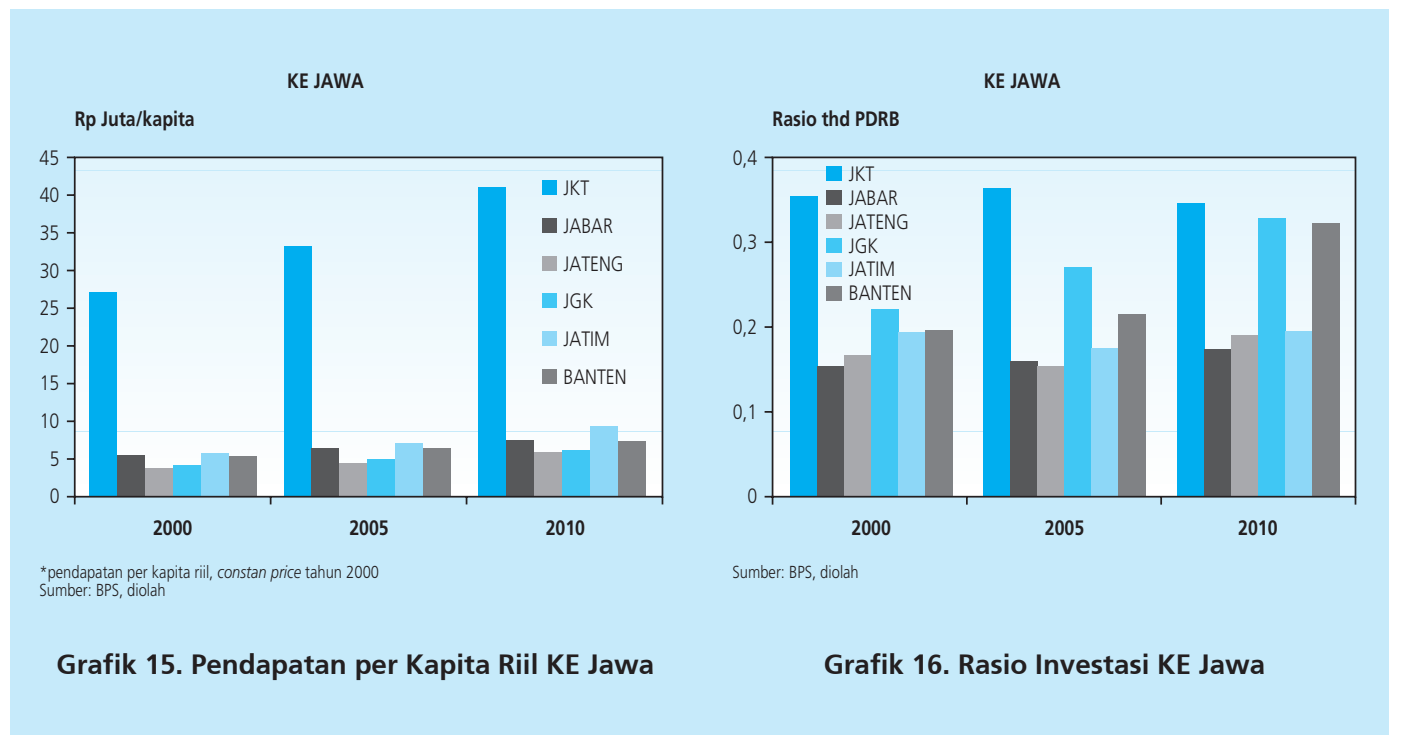

Dibandingkan dengan provinsi lain, DKI Jakarta memiliki rasio investasi yang lebih tinggi terutama sebelum tahun 2005 di mana rasio investasi DKI sudah mencapi 35\% dari Produk Domestik Bruto Daerah, sementara provinsi lainnya kurang dari 25\%. Di sisi lain, pendapatan riil per kapita DIY Yogyakarta dan Banten mengalami peningkatan seiring dengan semakin tingginya rasio investasi di kedua provinsi tersebut (Grafik 16). Dengan demikian, dapat diindikasikan bahwa kegiatan investasi yang semakin tinggi akan meningkatkan pendapatan riil per kapita.

\section{Koridor Ekonomi Bali dan Nusa Tenggara}

KE Bali dan Nusa Tenggara memiliki disparitas pendapatan riil yang cenderung lebih rendah dibandingkan dengan KE lainnya. ${ }^{12}$ Rata-rata pendapatan per kapita riil (2000-2010) provinsi di KE Bali dan Nusa Tenggara Rp. 4,1 juta dengan rincian Bali Rp. 6,3 juta, Nusa Tenggara Barat Rp.3,7 juta dan Nusa Tenggara Timur Rp. 2,3 juta (Grafik 17). Provinsi NTB mempunyai rasio investasi yang cukup tinggi selama sepuluh tahun terakhir namun pendapatan per kapita riilnya masih di bawah Bali (Grafik 18). Kemungkinan hal ini terkait dengan rendahnya level pendapatan per kapita riil NTB dibandingkan Bali, meskipun dalam rasio lebih besar namun secara level riil masih di bawah Bali. 


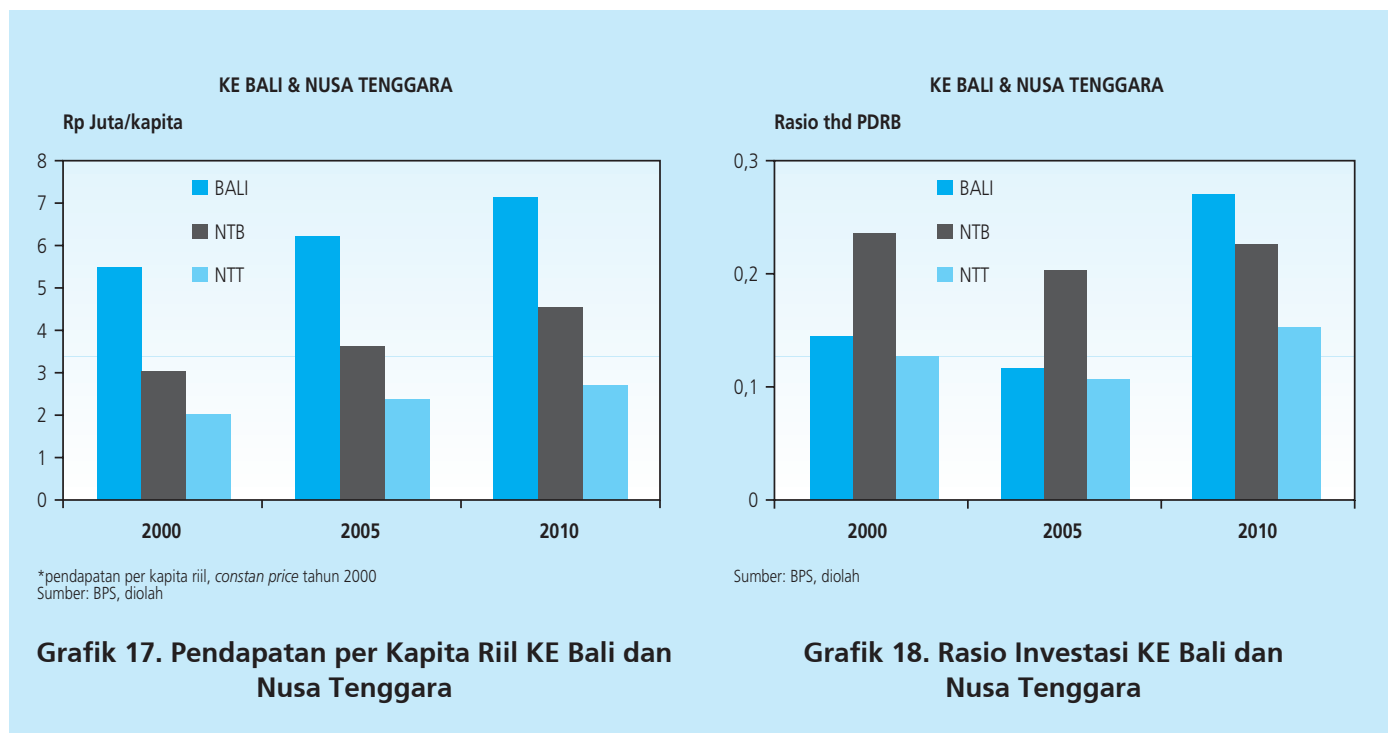

\section{Koridor Ekonomi Kalimantan}

Disparitas pendapatan per kapita riil mengalami penurunan yang cukup signifikan dalam sepuluh tahun terakhir. Gini coefficient turun dari 0,43 (tahun 2000) menjadi 0,34 (tahun 2010) meskipun angka ini belum termasuk kategori kesenjangan yang rendah menurut standar internasional. Penurun Gini coefficient ini selain didorong peningkatan pendapatan per kapita riil provinsi Kalimantan Barat, Kalimantan Tengah, dan Kalimantan Selatan, juga disebabkan oleh tren penurunan pendapatan per kapita riil Kalimantan Timur dalam sepuluh tahun terakhir. Hal ini disebabkan karena laju pertumbuhan ekonomi Kalimantan Timur lebih rendah dibandingkan dengan laju pertumbuhan penduduknya (Grafik 19).

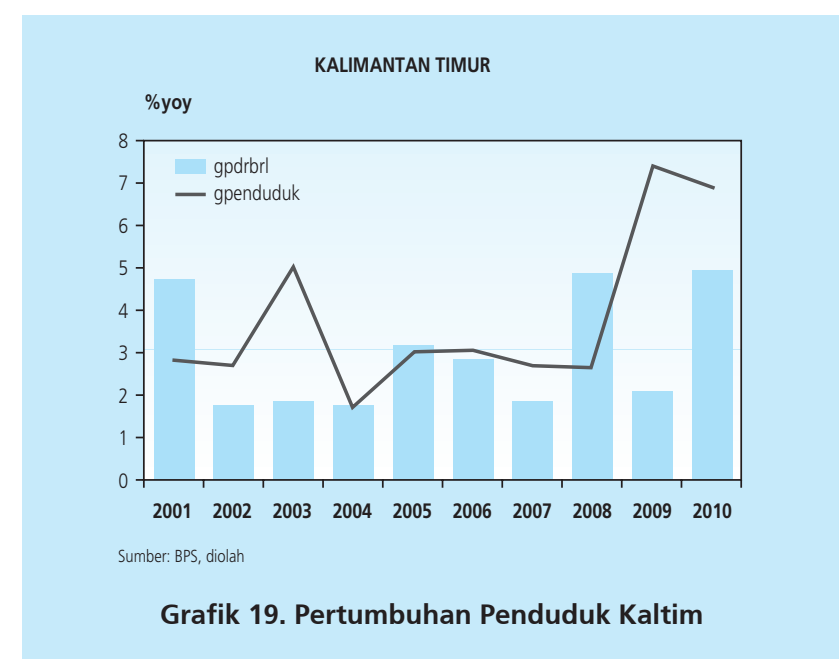


Pendapatan rata-rata per kapita (tahun 2000-2010) riil KE Kalimantan sebesar Rp.13,3 juta dengan provinsi Kalimantan Timur dengan pendapatan per kapita riil paling tinggi sebesar Rp. 32,9 juta. Sementara pendapatan per kapita riil provinsi-provinsi lainnya jauh di bawahnya, yaitu provinsi Kalimantan Barat sebesar Rp. 5,8 juta, Kalimantan Tengah dan Kalimantan Selatan masing-masing sebesar Rp. 7,2 juta (Grafik 20).

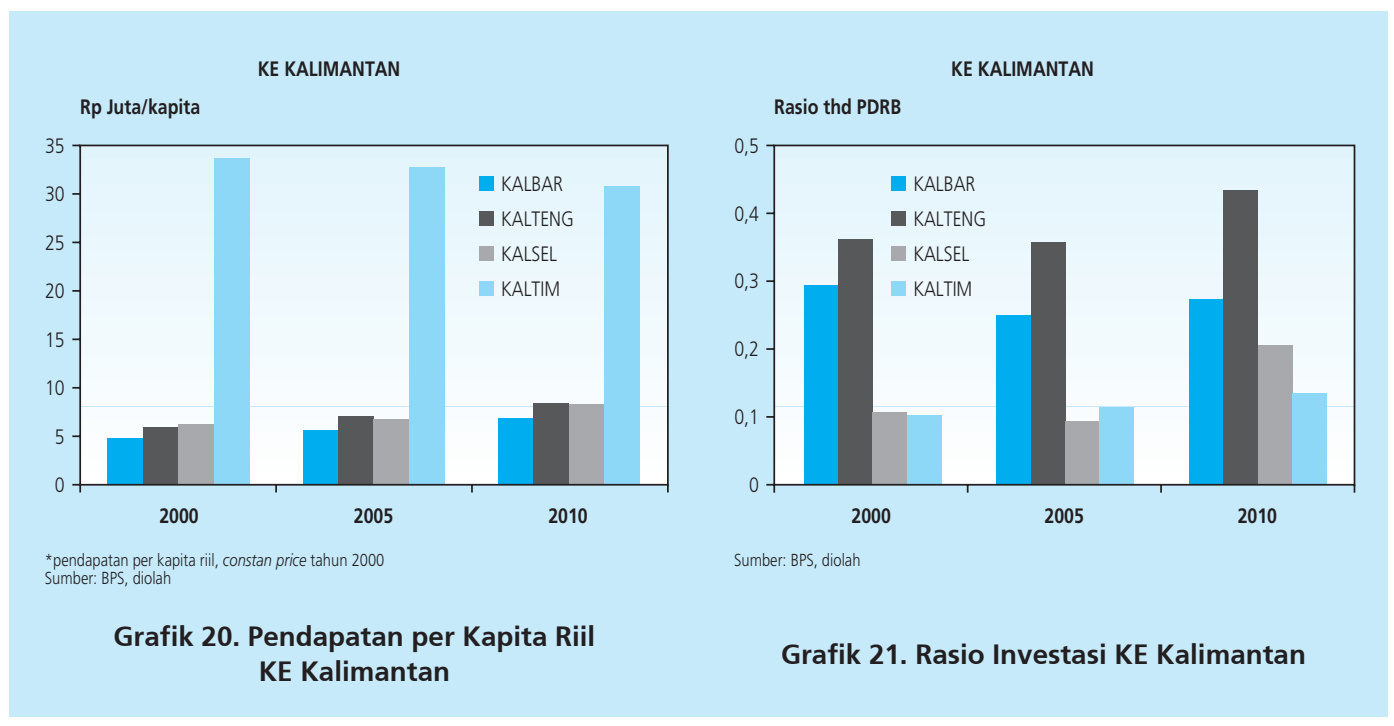

Secara historis, rasio investasi Kalimantan Barat dan Kalimantan Tengah lebih tinggi dibandingkan Kalimantan Timur (Grafik 21). Namun demikian, mengingat secara level pendapatan riil provinsi Kalimantan Barat dan Kalimantan Tengah masih jauh di bawah Kalimantan Timur ${ }^{13}$ maka kegiatan investasi di kedua provinsi tersebut belum mampu mendorong perekonomiannya menjadi sebaik Kalimantan Timur. Pertumbuhan ekonomi Kalimantar Timur diindikasikan digerakkan oleh kegiatan pertambangan di mana share pertambangan terhadap pendapatan daerah meningkat dari 34,78\% (tahun 2000) menjadi 40,11\% (tahun 2010).

\section{Koridor Ekonomi Sulawesi}

Koridor ekonomi Sulawesi memiliki economic equality terbaik dibandingkan dengan KE lainnya, dengan Gini coefficient masuk kategori rendah menurut standar internasional yaitu sekita 0,18 sepanjang sepuluh tahun terakhir. Pendapatan rata-rata per kapita riil (tahun 2000- 
2010) sebesar Rp. 4,5 juta dengan provinsi Sulawesi Utara tertinggi mencapai Rp. 6,3 juta dan terendah Gorontalo Rp. 2,2 juta (Grafik 22). Dari sisi rasio investasi, Gorontalo memiliki rasio investasi yang cukup tinggi namun belum mampu membawa perekonomian Gorontalo pada level rata-rata nasional (Grafik 23).

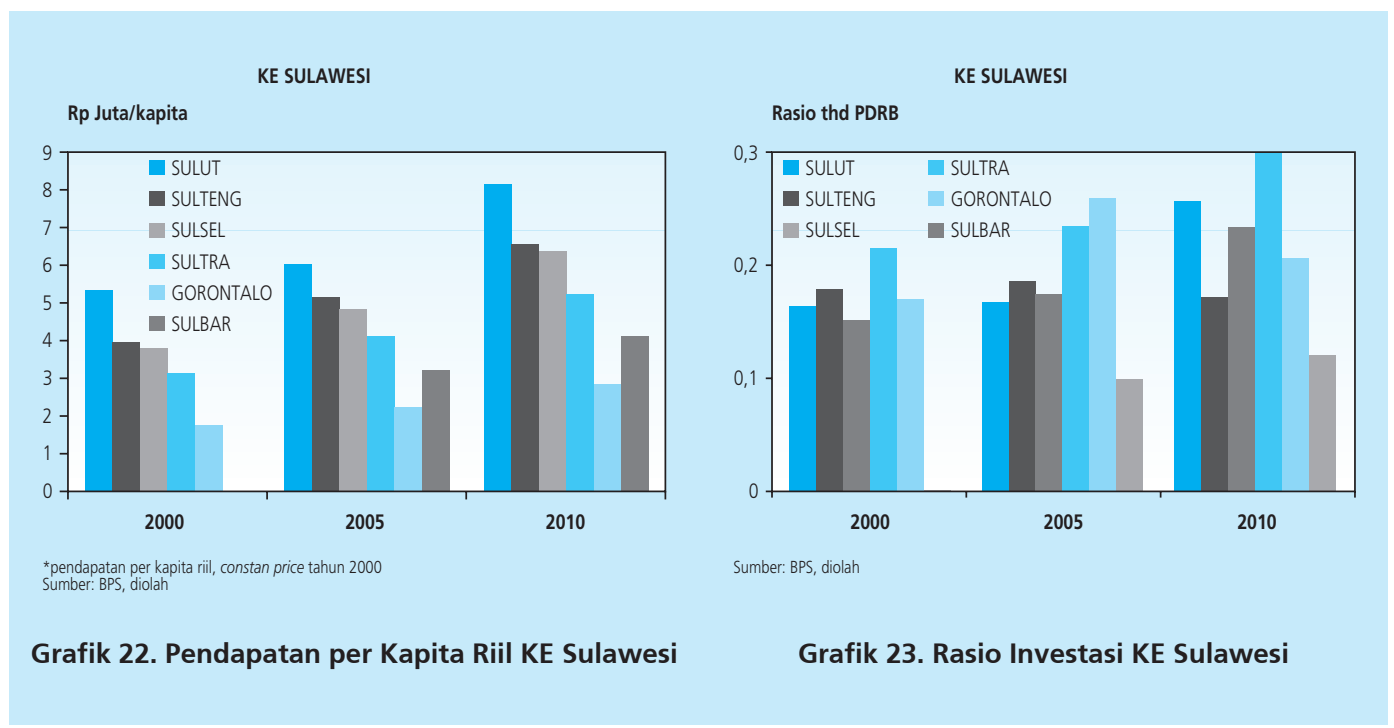

\section{Koridor Ekonomi Papua dan Kepulauan Maluku}

Dalam delapan tahun terakhir, disparitas pendapatan per kapita riil di KE Papua dan Kepulauan Maluku mengalami tren penurunan, namun pada dua tahun terakhir mengalami peningkatan yang moderat. Pendapatan rata-rata per kapita riil (tahun 2000-2010 KE Papua dan Kepulauan Maluku sebesar Rp. 5,5 Juta dengan pendapatan per kapita riil provinsi Papua sebesar Rp. 9,3 juta, Papua Barat sebesar Rp. 9,1 juta serta Maluku dan Maluku Utara sebesar Rp. 2,6 juta (Grafik 24). Selain dari sisi pendapatan per kapita riil, provinsi Papua dan Papua Barat secara historis memiliki rasio investasi yang lebih tinggi dibandingkan dengan Maluku dan Maluku Utara (Grafik 25). Hal ini mengindikasikan bahwa kegiatan investasi menjadi motor penggerak pertumbuhan ekonomi di provinsi Papua dan Papua Barat pendapatan per kapitanya meningkat secara gradual dalam sepuluh tahun terakhir. 


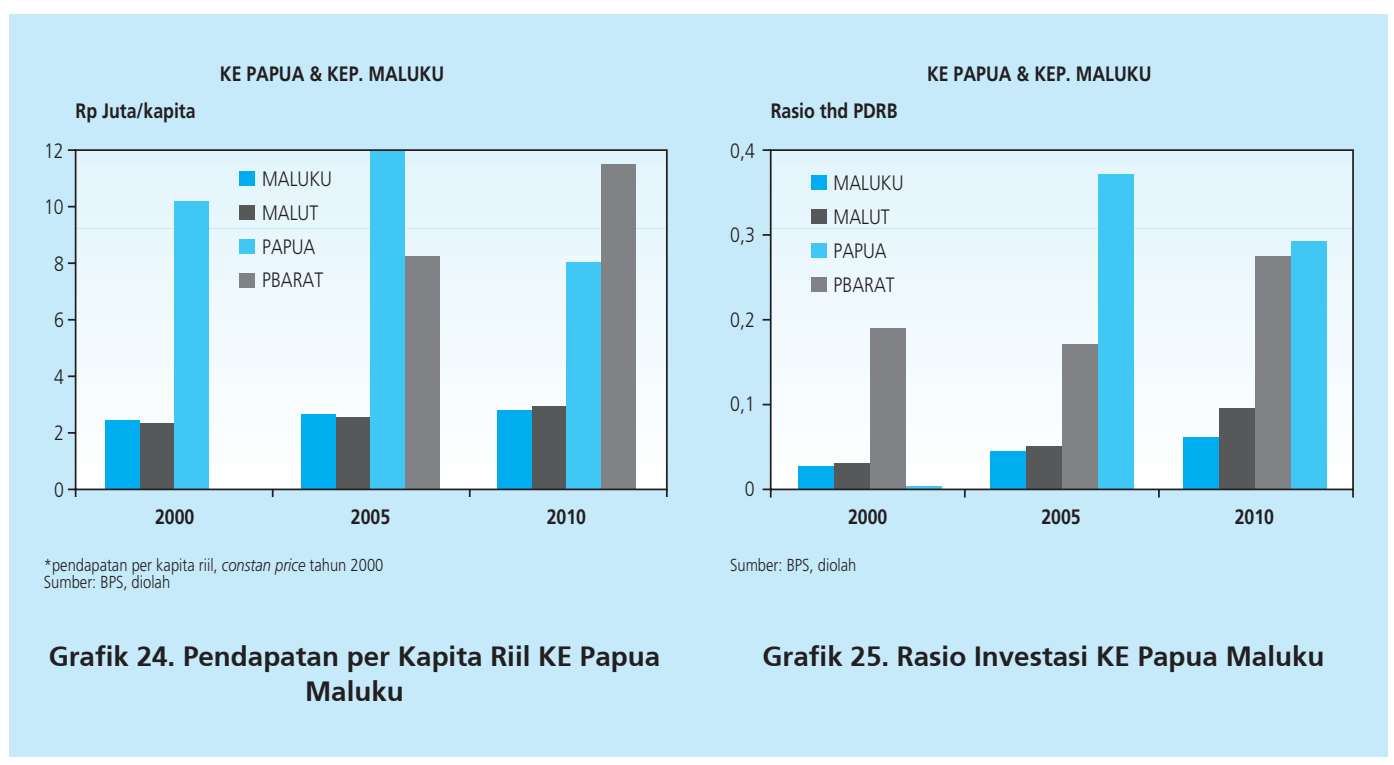

Pemerataan pendapatan riil dalam sepuluh tahun terakhir ini menunjukkan perkembangan yang kurang menggembirakan, dilihat baik dari rata-rata pendapatan per kapita riil di Koridor Ekonomi maupun perkembangan Gini coefficient. KE Jawa dan KE Kalimantan memiliki rata-rata pendapatan per kapita riil di atas rata-rata nasional namun disparitasnya masih cukup tinggi. Sementara KE Bali dan Nusa Tenggara serta KE Sulawesi yang memiliki Gini coefficient yang rendah menurut standar internasional mempunyai rata-rata pendapatan per kapita riil jauh di bawah rata-rata nasional. Kalimantan merupakan satu-satunya KE yang mengindikasikan adanya sigma convergence. Namun proses konvergensi ini selain didorong oleh pendapatan per kapita riil provinsi Kalimantan Barat, Kalimantan Tengah, dan Kalimantan Selatan juga karena adanya tren penurunan pendapatan per kapita riil provinsi Kalimantan Timur (Tabel 5). Idealnya, konvergensi merupakan proses catching up provinsi tertinggal terhadap provinsi kaya tanpa disertai penurunan pendapatan per kapita riil provinsi yang lebih kaya.

\begin{tabular}{l|c|c|c}
\multicolumn{5}{c}{ Tabel 5 } \\
\multicolumn{1}{c}{ Ringkasan Sigma Konvergensi Koridor Ekonomi } \\
Koridor Ekonomi & $\begin{array}{c}\text { Pendapatan } \\
\text { per Kapita Riil (Rp juta) }\end{array}$ & $\begin{array}{c}\text { Gini Coefficient } \\
\mathbf{( 2 0 1 0 )}\end{array}$ & Sigma Convergence \\
\hline Sumatera & 8,56 & 0,29 & Tidak \\
\hline Jawa & 10,57 & 0,40 & Tidak \\
\hline Balnustra & 4,1 & 0,21 & Tidak \\
\hline Kalimantan & 13,3 & 0,34 & Ya \\
\hline Sulawesi & 4,5 & 0,18 & Tidak \\
\hline Maluku-Papua & 5,5 & 0,31 & Tidak \\
\hline Sumber: BPS, diolah & & &
\end{tabular}




\section{2. $\beta$-Convergence}

Hasil estimasi dengan menggunakan GMM-system estimator untuk menangkap indikasi $\beta$-convergence ditunjukkan pada tabel berikut ${ }^{14}$. Uji robustness $A R(1)$ dan $A R(2)$ mendukung model telah bebas dari serial correlation di orde pertama. Di samping itu, statistik Hansen-diff juga mendukung validnya penggunaan variabel instrumental dalam model.

\begin{tabular}{|c|c|c|c|c|c|}
\hline \multicolumn{6}{|c|}{$\begin{array}{c}\text { Tabel } 6 \\
\text { Hasil Estimasi }\end{array}$} \\
\hline \multirow{2}{*}{ Variabel Independen } & \multicolumn{5}{|c|}{ Variabel Dependen: Pendapatan per Kapita } \\
\hline & OLS & Fixed & Random & GMM-S & Sys \\
\hline Konstanta & $\begin{array}{l}0.400 \\
4.000\end{array}$ *** & $\begin{array}{l}1.619 \\
5.070\end{array} * * *$ & $\begin{array}{l}0.400 \\
4.170\end{array}$ *** & $\begin{array}{l}0.442 \\
3.180\end{array}$ & *** \\
\hline lag Pendapatan per Kapita & $\begin{array}{r}0.862 \\
37.340 \quad * * *\end{array}$ & $\begin{array}{r}0.513 \\
10.100 \quad * * *\end{array}$ & $\begin{array}{r}0.862 \\
44.430 \quad * * *\end{array}$ & $\begin{array}{r}0.825 \\
17.620 \\
\end{array}$ & *** \\
\hline \multicolumn{6}{|l|}{ Akumulasi Faktor Produksi } \\
\hline Investasi & $\begin{array}{l}0.060 \\
5.800\end{array} \quad * * *$ & $\begin{array}{l}0.054 \\
1.750\end{array}$ * & $\begin{array}{l}0.060 \\
5.860\end{array}$ & $\begin{array}{l}0.081 \\
3.260\end{array}$ & *** \\
\hline Rata-rata Masa Sekolah & $\begin{array}{l}0.076 \\
1.530 \\
\end{array}$ & $\begin{array}{l}0.249 \\
3.560\end{array} * * *$ & $\begin{array}{l}0.076 \\
1.800\end{array}$ * & $\begin{array}{l}0.133 \\
2.100\end{array}$ & ** \\
\hline \multicolumn{6}{|l|}{ Infrastruktur dan Koridor } \\
\hline Listrik & $\begin{array}{l}0.052 \\
3.060\end{array} * * *$ & $\begin{array}{l}0.337 \\
5.620\end{array}$ & $\begin{array}{l}0.052 \\
3.270\end{array} * * *$ & $\begin{array}{l}0.088 \\
2.740\end{array}$ & ** \\
\hline Jalan & $\begin{array}{l}0.012 \\
1.140 \\
\end{array}$ & $\begin{array}{l}0.012 \\
0.780 \\
\end{array}$ & $\begin{array}{l}0.012 \\
1.160 \\
\end{array}$ & $\begin{array}{l}0.026 \\
1.950 \\
\end{array}$ & * \\
\hline Pelabuhan & $\begin{array}{l}0.009 \\
2.780\end{array}{ }^{* * *}$ & $\begin{array}{l}0.001 \\
0.120\end{array}$ & $\begin{array}{l}0.009 \\
2.350\end{array}$ & $\begin{array}{l}0.015 \\
2.110\end{array}$ & $* *$ \\
\hline \multicolumn{6}{|l|}{ Reformasi dan Struktur Ekonomi } \\
\hline Urbanisasi & $\begin{array}{l}0.009 \\
0.460\end{array}$ & $\begin{array}{l}-0.060 \\
-0.610 \\
\end{array}$ & $\begin{array}{l}0.009 \\
0.420\end{array}$ & $\begin{array}{l}-0.025 \\
-0.860\end{array}$ & \\
\hline Keterbukaan & $\begin{array}{l}0.008 \\
0.570\end{array}$ & $\begin{array}{l}0.053 \\
2.110 \text { ** }\end{array}$ & $\begin{array}{l}0.008 \\
0.710\end{array}$ & $\begin{array}{l}0.034 \\
2.090\end{array}$ & ** \\
\hline Pangsa Konsumsi Pemerintah & $\begin{array}{l}-0.022 \\
-1.690 *\end{array}$ & $\begin{array}{l}0.020 \\
0.510\end{array}$ & $\begin{array}{l}-0.022 \\
-1.430\end{array}$ & $\begin{array}{l}-0.054 \\
-3.130 \\
\end{array}$ & $* * *$ \\
\hline Pangsa Sektor Pertanian & $\begin{array}{l}-0.008 \\
-1.260\end{array}$ & $\begin{array}{l}-0.009 \\
-1.070\end{array}$ & $\begin{array}{l}-0.008 \\
-1.590\end{array}$ & $\begin{array}{l}-0.013 \\
-1.360\end{array}$ & \\
\hline $\begin{array}{l}\text { Observasi } \\
\operatorname{AR}(1) \\
\operatorname{AR}(1) \text { p-value } \\
\operatorname{AR}(2) \\
\text { AR(2) p-value } \\
\text { Hansen J } \\
\text { Hansen J p-value } \\
\text { Hansen-Diff J (GMM) } \\
\text { Hansen-Diff J (GMM) p-value } \\
\text { Hansen-Diff J (IV) } \\
\text { Hansen-Diff J (IV) p-value }\end{array}$ & & & & $\begin{array}{r}229 \\
-1.18 \\
(0.239 \\
0.70 \\
(0.482 \\
22.71 \\
(1.000 \\
-0.80 \\
(1.000 \\
0.79 \\
(1.000 \\
\end{array}$ & \\
\hline
\end{tabular}

14 Detail program tersedia pada penulis. 
Koefisien $\beta$ pada Tabel 6 di atas bertanda positif dan signifikan pada taraf nyata $1 \%$ dengan kecepatan konvergensi sebesar $1,75 \%{ }^{15}$ atau setara dengan half life sekitar 41,14 tahun ${ }^{16}$. Hasil empiris di atas mengindikasikan adanya $\beta$-convergence dalam perekonomian Indonesia, di mana provinsi-provinsi dengan pendapatan per kapita riil yang rendah cenderung untuk tumbuh lebih tinggi dibandingkan dengan provinsi-provinsi dengan pendapatan per kapita riil yang lebih tinggi (Grafik 26). Namun demikian, proses konvergensi memerlukan waktu yang cukup lama mengingat perbedaan pendapatan antara provinsi kaya dan miskin sangat lebar saat ini.

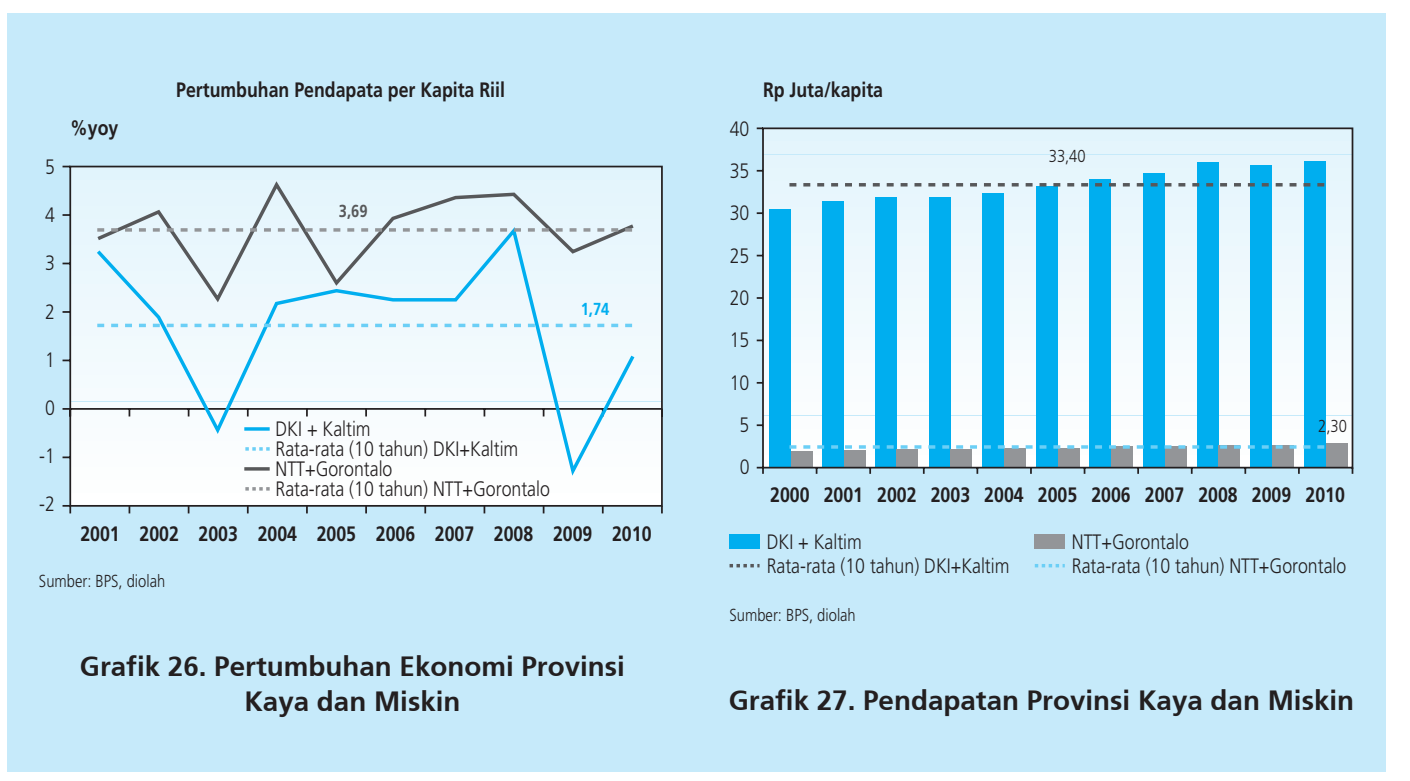

Meskipun terdapat indikasi adanya $\beta$-convergence, namun di dalam perekonomian Indonesia belum ditemukan indikasi adanya $\sigma$-convergence. Secara nasional, Indonesia mengalami peningkatan pendapatan per kapita riil dalam kurun waktu sepuluh tahun terakhir (Grafik 28). Namun demikian, pertumbuhan ekonomi selama ini mengindikasikan belum adanya pemerataan pendapatan riil per kapita di antara provinsi-provinsi di Indonesia. Terdapat beberapa provinsi dengan pendapatan per kapita jauh di atas rata-rata nasional ${ }^{17}$ misalnya DKI Jakarta dan Kalimantan Timur. Di sisi lain terdapat beberapa provinsi yang pendapatan riil

15 Dari persamaan (9), $\rho=e^{-\tau t}$ maka $0,825=e^{-\tau .11} \Leftrightarrow \tau=0,0175=1,75 \%$

16 Half-life merupakan waktu yang diperlukan agar setengah dari perbedaan pendapatan provinsi hilang karena proses konvergensi. Dihitung berdasarkan rumus half life $=72 / \tau=72 / 1,75=41,14$ tahun.

17 Rata-rata pendapatan per kapita riil nasional (2000-2010) sebesar Rp. 8,05 juta dengan median Rp. 5,9 juta. Hal ini menunjukkan bahwa distribusi pendapatan nasional skewed ke kanan yang artinya lebih banyak provinsi dengan pendapatan per kapita riil di bawah rata-rata nasional. 
per kapitanya masih jauh di bawah rata-rata nasional, misalnya provinsi Nusa Tenggara Timur dan Gorontalo (Grafik 29). Selain itu, terjadinya disparitas juga diindikasikan dari banyaknya provinsi yang pendapatan per kapita riilnya di bawah rata-rata nasional, misalnya pada tahun 2010 sebanyak 28 provinsi (84,8\% dari total provinsi) memiliki pendapatan per kapita riil di bawah rata-rata nasional. ${ }^{18}$

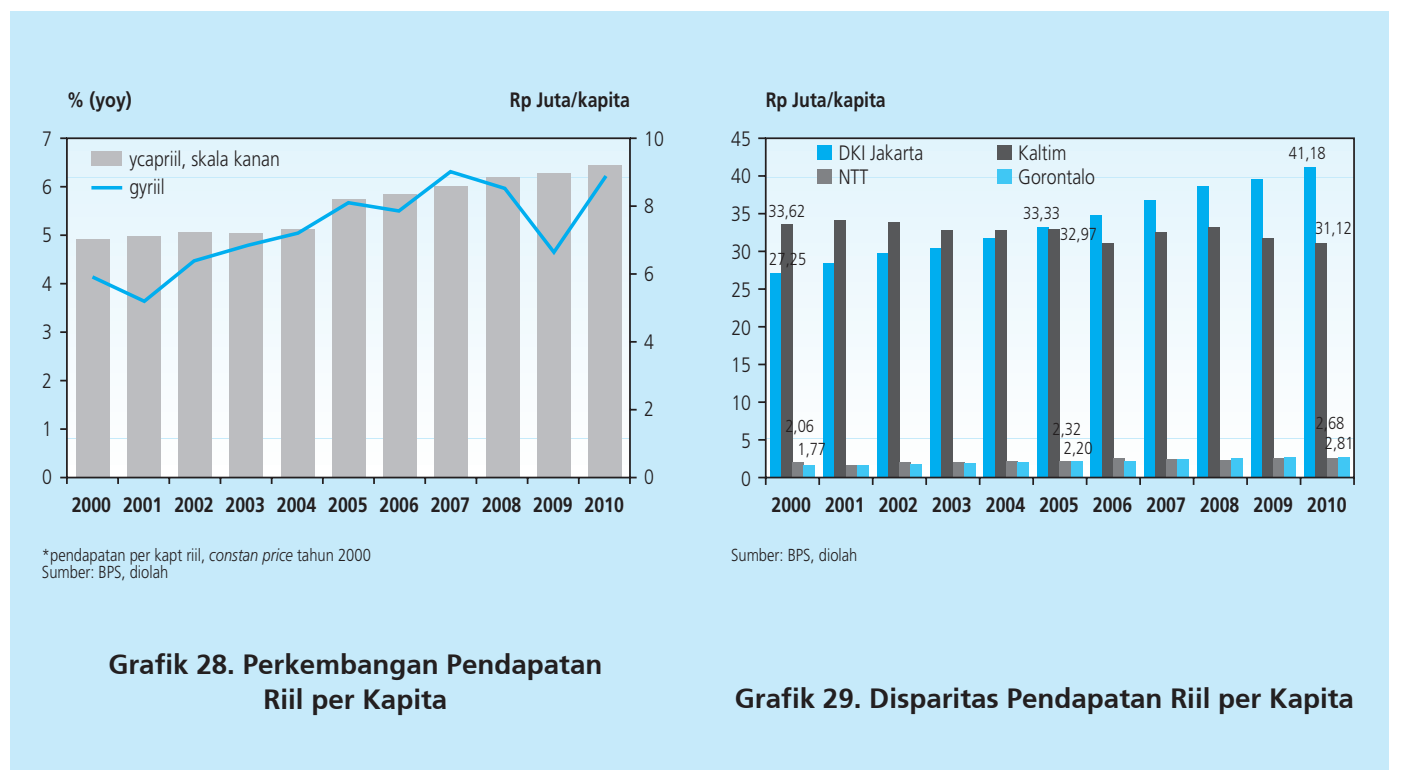

Hal ini berarti meskipun provinsi miskin telah berusaha tumbuh lebih tinggi namun belum tercapai adanya pemerataan pendapatan riil antara provinsi-provinsi di Indonesia (Grafik 27). Ketertinggalan tersebut salah satunya diakibatkan oleh jauh lebih rendahnya level awal pendapatan per kapita provinsi miskin sehingga berimplikasi pada terbatasnya ketersediaan modal yang salah satunya digunakan untuk meningkatkan daya dukung infrastruktur terhadap penciptaan pertumbuhan ekonomi daerah.

Pada blok faktor produksi kapital, modal fisik yang didekati oleh investasi berdampak positif signifikan, hal ini menguatkan dugaan awal bahwa investasi merupakan salah satu pendorong utama pertumbuhan ekonomi di Indonesia. Sementara rata-rata masa sekolah sebagai proksi dari modal manusia juga bertanda positif dan signifikan. Dengan demikian, faktor ketersediaan sumber daya manusia yang berkualitas berperan penting dalam menjelaskan adanya perbedaan pendapatan per kapita di wilayah Indonesia. Wilayah-wilayah yang mempunyai sumber daya manusia yang berkualitas cenderung memiliki pendapatan per kapita yang lebih tinggi. 
Dari sisi infrastruktur keras, listrik, jalan, dan bongkar muat pelabuhan berdampak positif dan signifikan dalam mendorong pendapatan per kapita. Dengan demikian, penyediaan infrastruktur dasar yang cukup baik secara kuantitas maupun kualitas, yaitu berupa listrik dan sarana transportasi baik jalan maupun laut merupakan prakondisi untuk mencapai pertumbuhan ekonomi yang tinggi dan berkesinambungan. Perlu digarisbawahi bahwa daya dukung infrastruktur di Indonesia masih lemah, (Global Competitiveness Report 2012-2013); dan ini terjadi hampir di semua aspek infrastruktur dasar, mulai dari masih rendahnya kualitas jalan, pelabuhan, bandara, kereta, hingga kualitas pasokan listrik (Tabel 7). Tantangan infrastruktur tersebut jika dapat dibenahi akan berpengaruh signifikan pada kesinambungan pertumbuhan ekonomi, termasuk pada pertumbuhan ekonomi regional di Indonesia.

\begin{tabular}{|c|c|}
\hline \multicolumn{2}{|c|}{$\begin{array}{c}\text { Tabel } 7 \\
\text { Kualitas Infrastruktur Indonesia }\end{array}$} \\
\hline Indikator & Peringkat \\
\hline Kualitas keseluruhan & 92 \\
\hline Kualitas jalan & 90 \\
\hline Kualitas infrastruktur kereta & 51 \\
\hline Kualitas infrastruktur pelabuhan & 104 \\
\hline Kualitas infrastruktur transportasi udara & 89 \\
\hline Kualitas pasokan listrik & 93 \\
\hline Sambungan telpon/100 penduduk & 78 \\
\hline
\end{tabular}

Perbandingan lintas provinsi menunjukkan bahwa dari sisi infrastruktur jalan koridor ekonomi (KE) Jawa memiliki keunggulan dibandingkan KE lainnya di mana rasio jalan per luas wilayah mencapai 0,81 km per km2 (rata-rata tahun 2000-2010). Kondisi ini jauh melebihi rata-rata nasional pada periode yang sama yaitu sebesar 0,34 km per $\mathrm{km} 2$. Sementara itu, KE Papua-Maluku yang hanya memiliki rasio jalan sebesar 0,05 km per km2.

Variabel lain yang digunakan dalam mengamati kondisi jalan di wilayah Indonesia yaitu rasio panjang jalan per kapita. Pada rasio ini terlihat bahwa KE Papua Maluku menempati posisi tertinggi dengan rasio pada tahun 2010 sebesar 6 km/orang. Kondisi yang berbeda dijumpai di KE Jawa di mana terdapat tingkat kepadatan penduduk yang sangat tinggi maka rasio panjang jalan per kapita hanya sebesar 0,8 km/orang. Hal ini mengindikasikan adanya kontradiksi dengan ketersediaan jalan per luas wilayah di atas. Dengan demikian, ketersediaan infrastruktur jalan tidak hanya diukur dengan rasio per luas wilayah namun juga mempertimbangkan rasio jalan per kapita. Kondisi yang terjadi di KE Jawa mengindikasikan bahwa ketersediaan jalan dalam melayani penduduk telah mencapai titik jenuh akibat terkonsentrasinya penduduk yang 
cukup besar dalam suatu wilayah yang tidak terlalu besar (dibandingkan dengan nasional). Hal ini diperkuat oleh Susantoro, Bambang \& Danang Parikesit (2004) yang menyatakan bahwa tingkat kepadatan penduduk secara langsung maupun tidak langsung mengurangi daya saing dari transportasi wilayah. Kondisi sosial demografis wilayah diyakini memiliki pengaruh terhadap kinerja transportasi di wilayah tersebut di mana tingkat kepadatan penduduk akan memiliki pengaruh signifikan terhadap kemampuan transportasi dalam melayani kebutuhan masyarakat. ${ }^{19}$

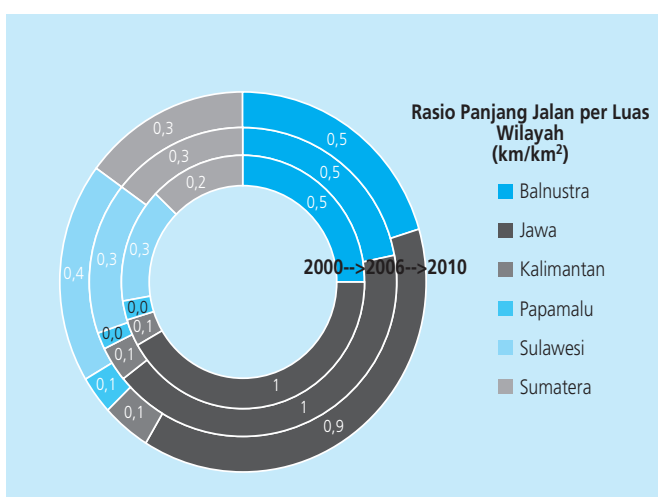

Sumber: BPS

Grafik 30. Rasio Panjang Jalan per Luas Wilayah

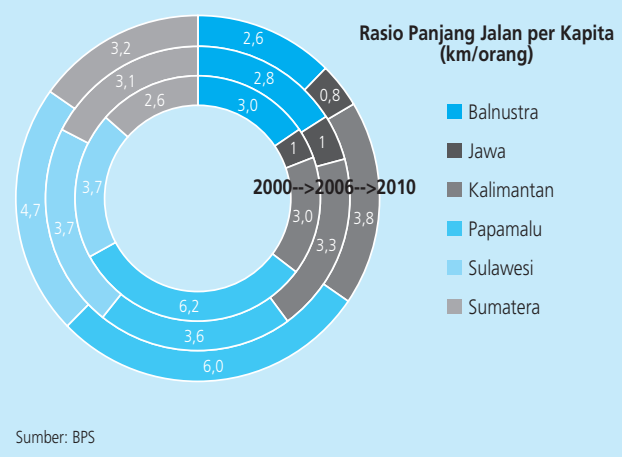

Grafik 31. Rasio Panjang Jalan per Kapita

Untuk variabel kontrol, urbanisasi tidak signifikan berpengaruh terhadap peningkatan pendapatan per kapita. Hal ini bisa diartikan bahwa cukup banyaknya masyarakat perkotaan yang cenderung bekerja di sektor manufaktur dan jasa belum cukup dapat mendorong pendapatan per kapita. Tidak meratanya pertumbuhan ekonomi menyebabkan adanya konsentrasi penduduk di wilayah perkotaan, karena selain mempunyai banyak lapangan pekerjaan, wilayah kota juga memiliki fasilitas pendidikan dan kesehatan yang lebih baik.

Jumlah penduduk yang tinggal di perkotaan terbesar berada di KE Jawa dengan mencapai angka sebesar 69\% pada tahun 2010, sedangkan rasio terendah berada di KE Papua Maluku di mana hanya $27 \%$ dari jumlah penduduk tinggal di wilayah perkotaan pada periode yang

19 Susantoro, Bambang \& Danang Parikesit, "1-2-3 Langkah: Langkah Kecil yang Kita LakukanMenuju Transportasi yang Berkelanjutan," Majalah Transportasi Indonesia, Vol. 1, Jakarta,2004:89-95 dalam S. Aminah: "Transportasi Publik dan Aksebilitas Masyarakat Perkotaan" Jurnal Masyarakat Kebudayaan Dan PolitikVolume 20, Nomor 1:35-52. 
sama. Rasio yang terus mengalami peningkatan dari tahun ke tahun ini dapat disebabkan oleh faktor penambahan jumlah penduduk kota itu sendiri dan juga adanya kegiatan urbanisasi. Hal yang perlu mendapat perhatian adalah perlunya pemerataan pusat kegiatan perekonomian untuk menghindari laju urbanisasi yang terlalu tinggi.

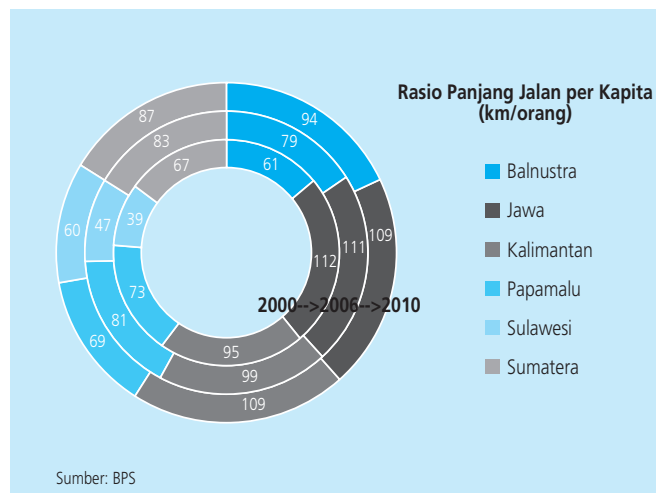

Grafik 32. Rasio Openness

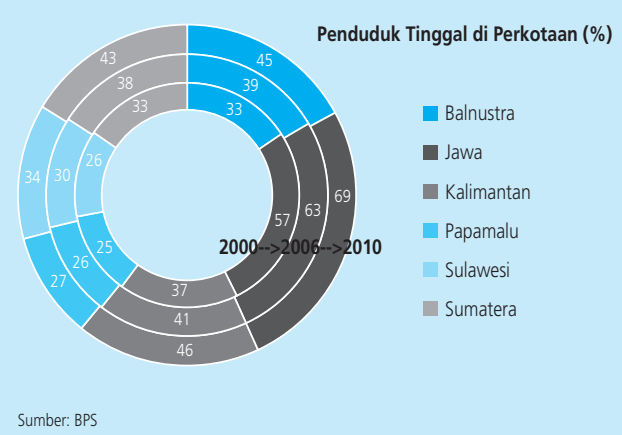

Grafik 33. Rasio Penduduk Tinggal di Perkotaan

Sementara itu, pangsa PDB sektor pertanian tidak secara signifikan berdampak terhadap pendapatan per kapita. Meski memiliki arah koefisien yang sama, hasil ini bertentangan dengan temuan Demurger (2001) yang menemukan koefisien sektor pertanian bernilai negatif dan signifikan terhadap pertumbuhan ekonomi. Arah koefisien yang negatif ini terkait dengan akses ke teknologi, wilayah yang bergantung pada sektor pertanian dalam perekonomiannya pada umumnya memiliki kesempatan yang lebih rendah untuk mendapatkan pengaruh positif dari teknologi baru apabila dibandingkan dengan wilayah yang menggantungkan perekonomiannya pada sektor industri yang relatif lebih dinamis.

Openness atau derajat keterbukaan berpengaruh secara positif dan signifikan dalam meningkatkan pendapatan per kapita. Seiring dengan peningkatan keterbukaan suatu wilayah, potensi untuk peningkatan produktivitas sebagai dampak positif dari spillover technology semakin besar yang pada akhirnya akan meningkatkan kesejahteraan masyarakatnya. Di sisi lain, variabel konsumsi pemerintah berdampak negatif dan signifikan. Hal ini mengindikasikan bahwa pemerintah daerah harus lebih bijaksana dalam mengelola anggarannya untuk pos-pos yang lebih produktif, misalnya belanja modal dan investasi. 


\section{KESIMPULAN}

Penelitian empiris ini memberikan beberapa kesimpulan menarik; pertama, resiliensi pertumbuhan ekonomi Indonesia telah berhasil meningkatkan rata-rata pendapatan per kapita riil nasional. Kedua, meskipun pendapatan per kapita riil nasional telah meningkat, namun belum terdapat pemerataan pendapatan per kapita riil antar provinsi di Indonesia. Ketiga, terdapat indikasi $\beta$-convergence dengan kecepatan konvergensi sebesar 1,75\% atau setara dengan half life sekitar 41,14 tahun. Dengan demikian, provinsi-provinsi dengan pendapatan per kapita riil lebih rendah tumbuh lebih tinggi dibandingkan dengan provinsi-provinsi dengan pendapatan per kapita riil lebih tinggi. Keempat, $\sigma$-convergence belum terjadi dalam perekonomian nasional Indonesia, yang artinya masih terdapat ketimpangan pendapatan per kapita riil antar provinsi di Indonesia. Kelima, kondisi infrastruktur jalan dan listrik berdampak signifikan terhadap pertumbuhan pendapatan per kapita, namun tidak demikian dengan pelabuhan. Terakhir, investasi terbukti secara empiris sebagai faktor pendorong pertumbuhan ekonomi Indonesia.

Perlu digarisbawahi bahwa penelitian ini mengasumsikan tidak adanya ketergantungan antar-wilayah dalam pengujian hipotesis konvergensi, dan ini merupakan asumsi yang terlalu restriktif. Pada sisi lain, interaksi antar-wilayah merupakan suatu keniscayaan, di mana secara natural suatu wilayah bersifat terbuka karena terjadi aliran ekonomi seperti perdagangan, difusi teknologi, dan mobilitas faktor produksi, yang dapat mempengaruhi konvergensi di masing-masing wilayah. Kedepan, penelitian ini perlu dikembangkan lebih lanjut dengan mempertimbangkan analisis spasial.

Kesimpulan di atas memiliki beberapa implikasi kebijakan; pertama, intervensi kebijakan Pemerintah untuk lebih mendorong pertumbuhan ekonomi provinsi-provinsi yang tertinggal. Hal ini terkait dengan ketimpangan pendapatan per kapita riil yang sangat besar di antara provinsi-provinsi di Indonesia sehingga diperlukan peran pemerintah yang lebih besar. Kedua, penggunaan anggaran secara bijaksana dengan lebih fokus pada pos-pos anggaran yang mendukung akumulasi kapital baik infrastruktur keras maupun human capital. Ketiga, perbaikan kondisi infrastruktur baik keras maupun lunak perlu terus diupayakan dengan mempertimbangkan aspek geografis dan kebutuhan wilayah. 


\section{DAFTAR PUSTAKA}

Arellano, M., dan S. Bond, (1991). Some Tests of Specification for Panel Data: Monte Carlo Evidence and an Application to Employment Equations. Review of Economic Studies, 58, 277-297.

Baltagi, B.H., (2005). Econometric Analysis of Panel Data. Chichester: John Wiley \& Sons Ltd., 4 th edition.

Badan Koordinasi Penanaman Modal, 2011. Indonesia Economic Observation 2011-2012: Membangun Sinergi Untuk Menghadapi Gejolak Ekonomi.

Badan Pusat Statistik, beberapa tahun. Statistik Indonesia. , beberapa tahun. Statistik Transportasi.

Bank Indonesia, (2012). Kajian Awal tentang Peran Infrastruktur dalam Pertumbuhan Ekonomi Daerah. Outlook Ekonomi Indonesia edisi Agustus 2012: Box 4.

Barro, R. J., dan X. Sala-i-Martin, (1992). Convergence. Journal of Political Economy, 100, 407-443.

Blundell, R., dan S. Bond, (1998). Initial Conditions and Moment Restrictions in Dynamic Panel Data Models. Journal of Econometrics, 87, 115-143.

Bouayad-Agha, S., dan L. Vedrine, (_). Estimation Strategies for Spatial Dynamic Panel Using GMM. A New Approach to the Convergence Issue of European Regions.

Calderón, C., dan L. Servén (2004). Trends in infrastructure in Latin America. World Bank Policy Research Working Paper 3401.

, (2006). The Effects of Infrastructure Development on Growth and Income Distribution. Working Paper n. 3400.

Calderón, C. E. Moral-Benito dan L. Servén (2011). Is Infrastructure Capital Productive? A Dynamic Heteregenous Approach, World Bank Policy Research Working Paper 5682

Canning, D., dan P. Pedroni, (2004). The Effect of Infrastructure on Long Run Economic Growth.

Caselli, F., dkk, (1996). Reopening the Convergence Debate: A New Look at Cross-Country Growth Empirics. Journal of Economic Growth.

Demurger, S., (2001). Infrastructure Development and Economic Growth: An Explanation for Regional Disparities in China? Journal of Comparative Economics 29, 95-117.

Efendic, A., dkk, (_). Institutions and Economic Performance: System GMM Modelling of Institutional Effects in Transition. 
Egert, B., dkk, (2009). Infrastructure and Growth: Empirical Evidence. OECD Economics Department Working Paper No. 685.

Firdaus, M., dan T. Irawan, (2010). Ekonometrika Untuk Data Panel (Aplikasi EViews dan Stata). Pelatihan di Bank Indonesia, Modul I-II.

Fisher, H., (2010). Introduction to Stata - Lecture 3: Panel Data.

Friedman, M. 1992. Do Old Fallacies Ever Die? Journal of Economics Literature 30, 2129.2132.

International Institute for Management Development, beberapa tahun. World Competitiveness Year Book.

Islam, N., (1995). Growth Empirics: A Panel Data Approach. Quarterly Journal of Economics, 110.

Kementerian Energi dan Sumber Daya Mineral, (2012). Arsip berita pada situs resmi ESDM http://www.esdm.go.id/berita/listrik/39-listrik/5716-lisdes-tingkatkan-rasio-elektrifikasinasional-menjadi-7295.html

Kementerian Koordinator Bidang Perekonomian, 2011. Masterplan Percepatan dan Perluasan Pembangunan Ekonomi Indonesia. 2011. Public Private Partnership Book 2011.

Kodoatie, R.J., (2003). Manajemen dan Rekayasa Infrastruktur. Pustaka Pelajar, Yogyakarta.

Kubis, A., dan L. Schneider, (2012). Human Capital Mobility and Convergence-A Spatial Dynamic Panel Model of the German Regions. IWH Discussion Papers No. 9, Oktober 2012, Halle Institute for Economic Research.

Mankiw, G. N., dkk, (1992). A Contribution to the Empirics of Economic Growth. Quarterly Journal of Economics, 107, 407-437.

Mileva, E., (2007). Using Arellano-Bond Dynamic Panel GMM Estimators in Stata: Tutorial with Examples using Stata 9.0 (xtabond and xtabond2). Economics Department, Fordham University.

Perusahaan Listrik Negara, beberapa tahun. Statistik PLN.

Podrecca, E., dan G. Carmeci, (2004). Education and Growth. A Dynamic Analysis with Panel Data.

Prasetyo, R.B., (2008). Ketimpangan dan Pengaruh Infrastruktur terhadap Pembangunan Ekonomi Kawasan Barat Indonesia (KBI). Departemen Ilmu Ekonomi, Fakultas Ekonomi dan Manajemen, Institut Pertanian Bogor.

, dan M. Firdaus, (2009). Pengaruh Infrastruktur pada Pertumbuhan Ekonomi Wilayah Indonesia. Jurnal Ekonomi dan Kebijakan Pembangunan, 2(2): 222-236. 
Quah, D.T., (1993). Galton's Fallacy and the Convergence Hypothesis. Scandinavian Journal of Economics 95, 427-443.

Ralhan, M., dan A. Dayanandan, (2005). Convergence of Income Among Provinces in Canada: An Application of GMM Estimation. Econometrics Working Paper EWP0502, Department of Economics, University of Victoria, Canada.

Roodman, D., (2009). How to Do xtabond2: An Introduction to Difference and System GMM in Stata. The Stata Journal (2009), 9, No. 1, pp. 86-136.

Sibarani, M.H.M., (2002). Kontribusi Infrastruktur terhadap Pertumbuhan Ekonomi Indonesia. Tesis Magister Sains. Program Pascasarjana, Universitas Indonesia, Jakarta.

Susantoro, B., dan D. Parikesit, (_). 1-2-3 Langkah: Langkah Kecil yang Kita Lakukan Menuju Transportasi yang Berkelanjutan. Majalah Transportasi Indonesia, Vol. 1, Jakarta, 2004:8995 dalam S. Aminah: "Transportasi Publik dan Aksebilitas Masyarakat Perkotaan" Jurnal Masyarakat Kebudayaan Dan PolitikVolume 20, Nomor 1:35-52.

Todaro, M.P., dan S.C. Smith, (2006). Pembangunan Ekonomi. Edisi ke-9. Erlangga, Jakarta.

United Nations Conference on Trade and Development, (2012). World Investment Prospect Survey 2012-2014.

United Nations Development Programme, beberapa tahun. Human Development Report.

N. Weil, David (2009). Economic Growth. Second Edition, Pearson Addison Wesley

World Bank, (1994). World Development Report: Infrastructure for Development. Oxford University Press, New York.

World Bank, (2012). Doing Business.

World Economic Forum, beberapa tahun. Global Competitiveness Report.

Wu, Y., (_). Income Disparity and Convergence in China's Regional Economies. Department of Economics, University of Western Australia.

Yanuar, R., (2006). Kaitan Pembangunan Infrastruktur dan Pertumbuhan Output serta Dampaknya terhadap Kesenjangan di Indonesia. Tesis Magister Sains. Program Pascasarjana IPB, Bogor.

Young, A. T., dkk, (2004). Sigma-Convergence Versus Beta-Convergence: Evidence from U.S. County-Level Data. 
98 Buletin Ekonomi Moneter dan Perbankan, Volume 17, Nomor 1, Juli 2014

halaman ini sengaja dikosongkan 